\title{
Assessment of Natural Radionuclides and Heavy Metal Concentrations in Marine Sediments in View of Tourism Activities in Hurghada City, Northern Red Sea, Egypt
}

\author{
Hesham Mahmoud Zakaly, ${ }^{1,2}$ Mohamed Amin Uosif, ${ }^{1,3}$ Hashem Madkour, ${ }^{4}$ \\ Mahmoud Tammam, ${ }^{1}$ Shams Issa, ${ }^{1,5}$ Reda Elsaman ${ }^{1}$ and Atef El-Taher ${ }^{1 *}$ \\ ${ }^{1}$ Physics Department, Faculty of Science, Al-Azhar University, \\ Assuit Branch, 71524 Assuit, Egypt \\ ${ }^{2}$ Department of Experimental Physics, Institute of Physics and Technology, \\ Ural Federal University, Yekaterinburg 620002, Russia \\ ${ }^{3}$ Physics Department, College of Science, Jouf University, \\ P.O. Box 2014, Sakaka, Saudi Arabia \\ ${ }^{4}$ National Institute of Oceanography and Fisheries, Red Sea Branch, \\ 84511 Hurghada, Egypt \\ ${ }^{5}$ Physics Department, College of Science, Tabuk University, \\ 11952, Kingdom of Saudi Arabia
}

*Corresponding author: atef.eltaher@gmail.com

Published online: 25 November 2019

To cite this article: Zakaly, H. M. et al. (2019). Assessment of natural radionuclides and heavy metal concentrations in marine sediments in view of tourism activities in Hurghada city, northern Red Sea, Egypt. J. Phys. Sci., 30(3), 21-47, https://doi.org/10.21315/ jps2019.30.3.3

To link to this article: https://doi.org/10.21315/jps2019.30.3.3

\begin{abstract}
The specific activity of ${ }^{40} \mathrm{~K},{ }^{232} \mathrm{Th}$ and ${ }^{226} \mathrm{Ra}$ in marine sediment samples collected from National Institute of Oceanography and Fisheries (NIOF) and Safier Hotel area in Hurghada city (the most important regions in Egypt), were measured by gamma ray spectrometry using $\mathrm{NaI}(\mathrm{Tl})$ detector. The values of specific activity varied from $7 \pm 1 \mathrm{~Bq} \mathrm{~kg} \mathrm{~kg}^{-1}$ to $53 \pm 4 \mathrm{~Bq} \mathrm{~kg}$, $6 \pm 1 \mathrm{~Bq} \mathrm{~kg} \mathrm{~kg}^{-1}$ to $32 \pm 6 \mathrm{~Bq} \mathrm{~kg}$, and from $167 \pm$ $11 \mathrm{~Bq} \mathrm{~kg} \mathrm{~kg}^{-1}$ to $1120 \pm 63 \mathrm{~Bq} \mathrm{~kg}{ }^{-1}$ for ${ }^{226} \mathrm{Ra},{ }^{232} \mathrm{Th}^{2}$ and ${ }^{40} \mathrm{~K}$, respectively. The heavy metals have been measured and analysed by atomic absorption spectrometer. The major range values of heavy metals concentrations in marine sediment samples were: $\mathrm{Cu}\left(10.5-78.0 \mu \mathrm{g} \mathrm{g}^{-1}\right), \mathrm{Zn}\left(21-150 \mu \mathrm{g} \mathrm{g}^{-1}\right), \mathrm{Pb}\left(30-53 \mu \mathrm{g} \mathrm{g}^{-1}\right), \mathrm{Cd}\left(2.50-4.00 \mu \mathrm{g} \mathrm{g^{-1 }}\right)$, Fe (5100-13150 $\left.\mathrm{g} \mathrm{g}^{-1}\right), \mathrm{Mn}\left(118-298 \mu \mathrm{g} \mathrm{g}^{-1}\right), \mathrm{Ni}\left(17-36 \mu \mathrm{g} \mathrm{g^{-1 } )}\right.$ and Co (16-18 $\left.\mu \mathrm{g} \mathrm{g^{-1 }}\right)$. The total organic matter (TOC) and carbonates $\left(\mathrm{CaCo}_{3}\right)$ distribution have been measured at some locations. Also, the frequency distribution and the value of $\left({ }^{232} \mathrm{Th} /{ }^{226} \mathrm{Ra}\right),\left({ }^{232} \mathrm{Th} /{ }^{40} \mathrm{~K}\right)$
\end{abstract}


and $\left({ }^{226} \mathrm{Ra}{ }^{40} \mathrm{~K}\right)$ ratio for all measured samples were determined. Additionally, evaluations have been made of the radiological hazards and the results are diagrammed by Surfer program in maps.

Keywords: Marine sediments, natural radioactivity, heavy metals, Red Sea, Egypt

\section{INTRODUCTION}

The main environmental problems and threats to the Red Sea coasts and aquatic environment locations include oil pollution, water pollution, solid waste disposal, navigation activities, phosphate ship pollution and fishing activities. ${ }^{1}$ As a result of human activities, pollution extends along the shore, and waste is discharged to the nearby shore waters. ${ }^{2}$ Mining, phosphate fertilisers manufacture, agricultural applications, coal combustion, cement production, street construction and other human activities are non-nuclear industries which have produced and redistributed increasing amounts of radioactive matters, leading to a considerable contribution radio-ecological pollution for these beaches. ${ }^{3}$ Some of these pollutants may directly or indirectly be captured by bottom sediments. ${ }^{4}$ Sediment acts as a medium of migration for transfer of radionuclides to the biological systems and hence, it is the basic indicator of radiological contamination of the environment. ${ }^{5}$

Beach sediments are mineral deposits formed through weathering and erosion of either igneous or metamorphic rocks. Among the rock constituent minerals, there are natural radionuclides that contribute to the ionising radiation exposure on earth. ${ }^{6}$ The natural radionuclides of the uranium and thorium series and ${ }^{40} \mathrm{~K}$ as well as the artificial radionuclides of ${ }^{137} \mathrm{Cs},{ }^{90} \mathrm{Sr}$ and ${ }^{239+240} \mathrm{Pu}$ are the major longlived radionuclides already present or introduced into seas. ${ }^{7}$ Biological effects of radionuclides in humans are due to physical and chemical processes that occur immediately after the passage of radiation through living matter. ${ }^{8,9}$ Therefore, the knowledge of concentration and distribution of natural radionuclide in the sediments along Red Sea coasts and aquatic environmental locations are of great interest since it provides useful information in monitoring the environmental contamination and associated human health by natural radioactivity. Heavy metal pollution of the aquatic environment has become a worldwide problem. Metals like arsenic, cadmium, chromium, mercury, nickel and lead are often considered indicators of anthropogenic influence in marine environment and are of potential risk to the natural environment. ${ }^{10,11} \mathrm{~A}$ number of researchers have demonstrated that the evaluation of metal distribution in marine shore is of great importance as a result of high pollution of heavy metals. ${ }^{12}$ Hence, assessing and tracking the abundance of these heavy metals in coastal ecosystem are an important task. 
The aim of this study is to compare the concentrations of natural radionuclides at two different stations. The first is National Institute of Oceanography and Fisheries (NIOF) and the second is Safier Hotel area, which was nurture station as well as a centre for research activities and at second was adding external sediments from the red mounts to expand the beaches of the Hotel Safire. Measurement of radiological hazard of populations is done to provide a background data on natural radioactive isotopes for the studied region.

\section{EXPERIMENTAL}

\subsection{Study Area}

NIOF is located about $5 \mathrm{~km}$ north of Hurghada city, between $27^{\circ} 17^{\prime} 07^{\prime \prime} \mathrm{N}$ and $33^{\circ}$ 46' 30" E (Figure 1). The location does not affect the activities of anthropogenic; it is distinguished by high sedimentation rate. This site is characterised by a long patchy reef, representing the front edge of a wide and shallow reef flat with many depressions and lagoons. Seaward of the reef edge is mostly a shallow sandy bottom area extending a long distance with few coral patches. The depth ranges from $3 \mathrm{~m}$ at the reef front with gentle slope towards depth water. The area is generally exposed to strong waves and the currents follow the prevailing current direction in the Red Sea from north to south. Fishing is considered a major activity in this area, mainly net fishing on the reef flat and the lagoons. A medium development does undergo along the coast of this area. The source rock at NIOF is composed of limestone and raised reefs; the back-shore area is occupied by buildings of El-Aheaa. The bottom topography of this area is characterised by sea grasses and algae in intertidal and subtidal area in addition to coral. An extended reef flat with seagrass and seaweed beds suitable for fish and shellfish breeding characterises this site. ${ }^{13}$

Safier Hotel area is one of Hurghada resorts which is located $8 \mathrm{~km}$ south of Hurghada at $27^{\circ} 12^{\prime} 14^{\prime \prime} \mathrm{N}$, and $33^{\circ} 51^{\prime} 07^{\prime \prime}$ E, seen in Figure 1. Most of the activities taking place in the area are landfilling, dredging and reclamation of the intertidal zone. The filling operations have been carried out above the setback line area and around the dredged lagoon in the intertidal zone and violated two small channels have been dredged in the intertidal zone for water circulation inside lagoon. Nets are mounted at the entrances of the channels to prevent the marine litters from entering the lagoon. Currently, the original coastline of this area has been completely altered by dredging and land filling operations. Landfilling results in burying and obliteration of a number of biologically productive intertidal and 
subtidal habitats. The seabed in the area is covered by patches of seagrasses and algae with coral fragments. The bottom facies are characterised by many patches of seagrasses, algae and coral reefs.
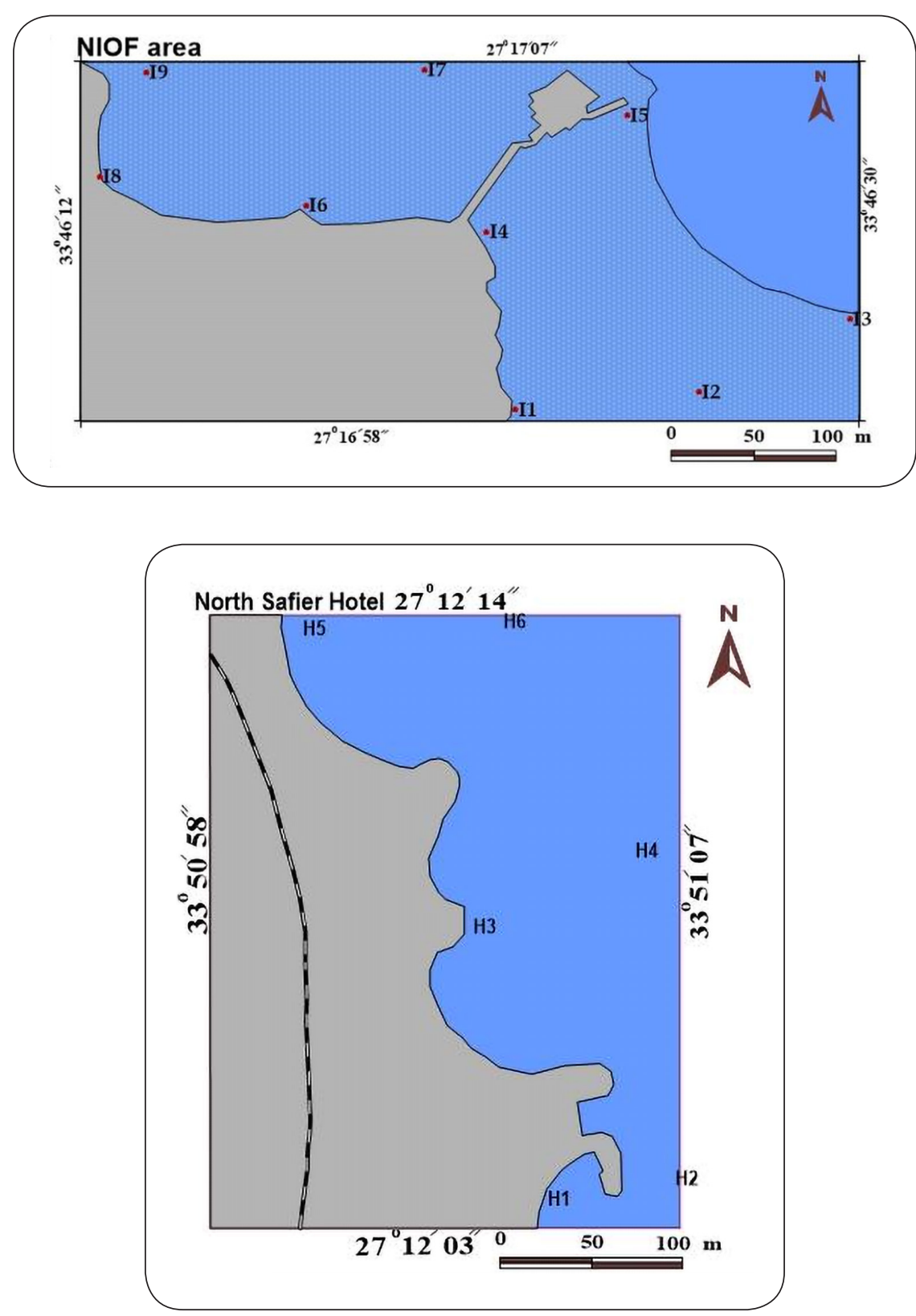

Figure 1: Location map of samples in the studied area. 


\subsection{Samples Collection and Preparation}

The sediment samples have been collected from Hurghada City (nine samples from NIOF area, coded with I1 to I9, and six samples from North Safier Hotel, coded with $\mathrm{H} 1$ to H6) as shown in Figure 1. Sediment samples were collected by hand, grab sampler and scuba diving. The physical criteria of water, i.e., temperature, salinity, $\mathrm{pH}$, depth, specific conductivity (SPC) and total dissolved salts (TDS), were measured directly in the field using Hydrolab Instrument (HANNA HI 9828) during samples collection at the studied localities, shown in Table 1 . The salinity of seawater ranged from $42.3 \%$ to $42.47 \%$ at depth $0.5 \mathrm{~m}$ and $0.8 \mathrm{~m}$, respectively. On the other hand, the water temperature ranges between $22.1^{\circ} \mathrm{C}$ at depth $25 \mathrm{~cm}$ and $22.13^{\circ} \mathrm{C}$ at depth $30 \mathrm{~cm}$, as shown in Table 1 .

Table 1: The hydrographic parameters of water mass in the studied areas.

\begin{tabular}{lccccccc}
\hline Region & $\begin{array}{c}\text { Depth } \\
(\mathrm{cm})\end{array}$ & PH & $\begin{array}{c}\text { Sal. } \\
(\%)\end{array}$ & $\begin{array}{c}\text { Temp. } \\
\left({ }^{\circ} \mathrm{C}\right)\end{array}$ & $\begin{array}{c}\text { TDS } \\
(\mathrm{ppt})\end{array}$ & $\begin{array}{c}\text { Sea water, } \\
\text { vspec.grav }(\sigma \mathrm{\sigma})\end{array}$ & $\begin{array}{c}\text { SPC } \\
\left(\mathrm{ms} \mathrm{cm}^{-1}\right)\end{array}$ \\
\hline North Safier & 30 & 8.62 & 42.33 & 22.13 & 31.33 & 29.8 & 62.70 \\
Hotel & 25 & 8.00 & 42.33 & 22.10 & 31.35 & 29.0 & 62.70 \\
& 35 & 8.64 & 42.31 & 21.83 & 31.34 & 29.8 & 62.69 \\
NIOF area & 1.0 & 8.50 & 42.47 & 21.57 & 31.43 & 30.0 & 62.87 \\
& 0.5 & 8.49 & 42.30 & 21.53 & 31.38 & 30.0 & 62.77 \\
& 0.8 & 8.50 & 42.47 & 21.57 & 31.43 & 30.0 & 62.87 \\
\hline
\end{tabular}

To determine the carbonate content, $1 \mathrm{~g}$ of each prepared sample was treated by 1N HCL acid, filtered and washed away several times by distilled water, dried and reweighed in order to calculate the percentage of carbonate content of the sediments. For organic carbon and total organic matter, $1 \mathrm{~g}$ of each crude sample was burned to $550^{\circ} \mathrm{C}$ for about $2 \mathrm{~h}$. The organic matter content of the sediments was determined by sequential weight loss at $550^{\circ} \mathrm{C}$. In case of heavy metals, about $0.5 \mathrm{~g}$ of homogenised ground sediment samples were accurately weighed on an analytical balance and then transferred into a Teflon beaker and were completely digested by using a mixture of concentration. ${ }^{5}$ Nitric, per chloric and hydrofluoric acids were mixed with the ratio $3: 2: 1$, respectively. ${ }^{14}$

For gamma spectroscopic analysis, each sample was dried in an oven at $110^{\circ} \mathrm{C}$ for $48 \mathrm{~h}$ to ensure that moisture is completely removed. The samples were crushed, homogenised and sieved through a $200 \mu \mathrm{m}$. Weighted samples were placed in polyethylene beaker, of $350 \mathrm{~cm}^{3}$ volume each and weighted. The beakers were completely sealed for 4 weeks to reach secular equilibrium radium and thorium, and their progenies. ${ }^{15}$ 


\subsection{Gamma Spectrometric Analysis}

Activity measurements have been performed by gamma-ray spectrometer, employing a scintillation detector $(7.62 \times 7.62 \mathrm{~cm})$. It had a hermetically sealed assembly, which included a $\mathrm{NaI}(\mathrm{Tl})$ crystal, coupled with a PC-MCA Canberra Accuspec. To reduce the gamma-ray background, a cylindrical lead shield $(100 \mathrm{~mm}$ thick) with a fixed bottom and movable cover shielded the detector. The lead shield contained an inner concentric cylinder of copper $(0.3 \mathrm{~mm}$ thick) in order to absorb $\mathrm{X}$-rays generated in the lead. In order to determine the background distribution in the environment around the detector, an empty sealed beaker was counted in the same manner and in the same geometry as the samples. ${ }^{16}$ The measurement period of the activity or background was $43,200 \mathrm{~s}$. The background spectra were used to correct the net peak area of the gamma rays of the measured isotopes. A dedicated software program was used. ${ }^{17}$ The calculations were done using the MS Excel program.

The ${ }^{226} \mathrm{Ra}$ radionuclide was estimated from the $351.9 \mathrm{keV} \gamma$-peak of ${ }^{214} \mathrm{~Pb}$, and $609.3 \mathrm{keV}, 1120.3 \mathrm{keV}, 1728.6 \mathrm{keV}$ and $1764 \mathrm{keV} \gamma$-peak of ${ }^{214} \mathrm{Bi}$. The ${ }^{232} \mathrm{Th}$ radionuclide was estimated from the $911.2 \mathrm{keV} \gamma$-peak of ${ }^{228} \mathrm{Ac}$ and the $238.6 \mathrm{keV}$ $\gamma$-peak of ${ }^{212} \mathrm{~Pb}$. The ${ }^{40} \mathrm{~K}$ radionuclide was estimated using the $1461 \mathrm{keV} \gamma$-peak from ${ }^{40} \mathrm{~K}$ itself. ${ }^{18-20}$

\subsection{Analytical Method}

\subsubsection{Concentration and uncertainty of activity}

The specific activity in $\mathrm{Bq} \mathrm{kg}^{-1}$ (A) in the sediment samples was obtained as follows:

$$
\mathrm{A}=\frac{\mathrm{N}_{\mathrm{p}}}{\mathrm{e} \times \eta \times \mathrm{m}}
$$

where $N_{p}$ is the count per second of sample (cps), e is the abundance of the $\gamma$-peak in radionuclide, $\eta$ is the measured efficiency for each gamma line observed for the same number of channels either for the sample, and $\mathrm{m}$ is sample mass in $\mathrm{kg}$.

\subsubsection{Radium equivalent activities}

The radium equivalent activities $\left(\mathrm{Ra}_{\mathrm{eq}}\right)$ have been calculated on the estimation that $370 \mathrm{~Bq} \mathrm{~kg}{ }^{-1}$ of ${ }^{226} \mathrm{Ra}, 259 \mathrm{~Bq} \mathrm{~kg}{ }^{-1}$ of ${ }^{232} \mathrm{Th}$ and $4810 \mathrm{~Bq} \mathrm{~kg}^{-1}$ of ${ }^{40} \mathrm{~K}$ produce the same gamma ray dose rate. ${ }^{21}$ Therefore, the $\mathrm{Ra}_{\mathrm{eq}}$ was estimated by Equation $2:^{22}$

$$
\mathrm{Ra}_{\mathrm{eq}}=\mathrm{A}_{\mathrm{Ra}}+1.43 \mathrm{~A}_{\mathrm{Th}}+0.077 \mathrm{~A}_{\mathrm{k}}
$$

where $A_{\text {Ra }}, A_{T h}$ and $A_{K}$ are the activities of ${ }^{226} \mathrm{Ra},{ }^{232} \mathrm{Th}_{\text {and }}{ }^{40} \mathrm{~K}\left(\mathrm{~Bq} \mathrm{~kg}{ }^{-1}\right)$, respectively. 


\subsubsection{Absorbed gamma dose rate}

The absorbed dose rates (D) due to gamma radiations in air at $1 \mathrm{~m}$ above the ground surface for the uniform distribution of the naturally occurring radionuclides $\left({ }^{226} \mathrm{Ra}\right.$, ${ }^{232} \mathrm{Th}$ and ${ }^{40} \mathrm{~K}$ ) were calculated. ${ }^{14}$ The $\mathrm{D}$ value can be calculated from Equation 3:

$$
\mathrm{D}=0.462 \mathrm{~A}_{\mathrm{Ra}}+0.604 \mathrm{~A}_{\mathrm{Th}}+0.0417 \mathrm{~A}_{\mathrm{K}}
$$

where $A_{R a}, A_{T h}$ and $A_{K}$ are the same as in Equation 2.

\subsubsection{Internal hazard index}

On the other hand, the internal hazard index $\left(\mathrm{H}_{\text {in }}\right)$ gives the internal exposure to carcinogenic radon and its short-lived progeny and it is given by the following formula: ${ }^{24-26}$

$$
\mathrm{H}_{\mathrm{in}}=\left(\mathrm{A}_{\mathrm{Ra}} / 185+\mathrm{A}_{\mathrm{Th}} / 259+\mathrm{A}_{\mathrm{K}} / 4810\right) \leq 1
$$

where $A_{\text {Ra }}, A_{T h}$ and $A_{K}$ are the same as in Equation 2.

\subsubsection{Gamma radiation hazard index}

In order to examine whether the samples meet the limit of dose criteria, another radiation hazard index, the representative level index $I \gamma$ is used to estimate the level of gamma-radiation hazard associated with the natural radionuclides in the investigated samples and is defined from the following formula. ${ }^{27}$

$$
\mathrm{I}_{\gamma}=0.0067 \mathrm{~A}_{\mathrm{Ra}}+0.01 \mathrm{~A}_{\mathrm{Th}}+0.00067 \mathrm{~A}_{\mathrm{K}}
$$

where $A_{R a}, A_{T h}$ and $A_{K}$ are the same as in Equation 2.

\subsubsection{Annual effective dose}

Annual estimated average effective dose equivalent (AED) received by an individual was calculated using a conversion factor of $0.7 \mathrm{SvG} \mathrm{y}^{-1}$, which was used to convert the absorbed rate to the human effective dose equivalent. ${ }^{14}$ The annual effective dose was evaluated using Equation 7:

$$
\mathrm{AED}=\mathrm{D} \times \mathrm{T} \times \mathrm{F}
$$

where $\mathrm{T}$ is the occupancy time and $\mathrm{F}$ is the conversion factor $\left(0.7 \mathrm{SvG}^{-1}\right)$. 


\subsubsection{Excess Lifetime Cancer Risk}

Excess lifetime cancer risk (ELCR) can be defined as the excess probability of developing cancer at a lifetime due to exposure level of human to radiation. ELCR was calculated by using the following equation: ${ }^{28}$

$$
\mathrm{ELCR}=\mathrm{EDR} \times \mathrm{DL} \times \mathrm{RF}
$$

where EDR is the annual effective dose equivalent, DL is the duration of life (3070 year) and $\mathrm{RF}$ is a risk factor $\left(\mathrm{Sv}^{-1}\right)$ fatal cancer risk per Sievert. For stochastic effects, International Commission on Radiological Protection (ICRP) 60 uses values of $\mathrm{RF}=0.05$ for public. ${ }^{14}$ The worldwide recommended value is $0.29 \times 10^{-3}$.

\section{RESULTS AND DISCUSSION}

\subsection{Sediment Types, Calcium Carbonates and Total Organic Matter}

The values of sediment types, carbonates $\left(\mathrm{CaCo}_{3}\right)$ and total organic matter (TOM) are presented in Table 2. From Table 2, we can observe that the values of sediment types in samples from Safier Hotel are between $1.27 \%$ and $10.31 \%$ with an average of $4.7 \%$, between $89.69 \%$ and $98.61 \%$ with an average of $94.8 \%$, and between $0.00 \%$ and $2.37 \%$ with an average of $0.5 \%$ for gravel, sand and mud, respectively. In samples from NIOF, the values of gravel, sand and mud fluctuate from $0.41 \%$ to $19.75 \%$ with an average of $13.09 \%$, ranged from $78.08 \%$ to $98.52 \%$ with an average of $85.57 \%$, and from $0 \%$ to $3.21 \%$ with an average of $1.34 \%$, respectively. The purpose of such mechanical analysis of the sediment is not only for the nature of the sediment but also to understand the physical properties of the sediments, and reveal the relationship and effect of the grain size, source materials and depositional environment. Figure 2 shows the distributions of gravel, sand and mud in sediment samples from the studied regions.

The average values of carbonates content in the investigated sediments fluctuate from $40.08 \%$ (Safier Hotel) to $48.87 \%$ (NIOF). As shown in Table 2, NIOF areas recorded the highest mean value of carbonate contents. This may be due to inorganic chemical precipitation, limestone rock on the sea floor residual from weathering and accumulation of skeletal grains.$^{29}$ Organic matter affects the aquatic ecosystem by interacting with organic matter to form complex compounds, which in its structure contain several other elements. ${ }^{30}$ The content of organic matter in sediment samples vary from $6.90 \%$ to $14.40 \%$ (Safier Hotel) and from $3.10 \%$ to $42.35 \%$ (NIOF) as shown in Table 3 and Figure 3. 
Table 2: Sediment types of samples at the study areas.

\begin{tabular}{|c|c|c|c|c|c|c|c|}
\hline \multirow{2}{*}{ Area } & \multirow{2}{*}{ Location } & \multicolumn{2}{|c|}{ Position } & \multirow{2}{*}{ Sample code } & \multicolumn{3}{|c|}{ Sediment type and percentage } \\
\hline & & Lat. & Long. & & Gravel & Sand & Mud \\
\hline \multirow{17}{*}{ 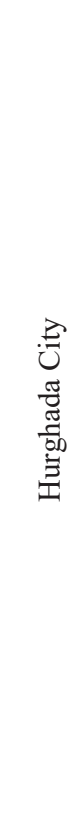 } & \multirow{6}{*}{ 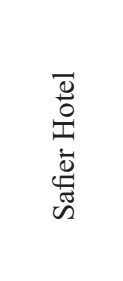 } & \multirow{6}{*}{$\begin{array}{l}\stackrel{0}{a} \\
\stackrel{\sim}{\sim} \\
\stackrel{\sim}{v}\end{array}$} & \multirow{6}{*}{$\begin{array}{l}\hat{o} \\
\text { nn } \\
\hat{n}\end{array}$} & H1 & 8.70 & 91.19 & 0.11 \\
\hline & & & & $\mathrm{H} 2$ & 5.54 & 94.46 & 0.00 \\
\hline & & & & H3 & 1.39 & 98.61 & 0.00 \\
\hline & & & & $\mathrm{H} 4$ & 10.31 & 89.69 & 0.00 \\
\hline & & & & H5 & 1.28 & 98.34 & 0.38 \\
\hline & & & & H6 & 1.27 & 96.36 & 2.37 \\
\hline & \multicolumn{4}{|c|}{ Mean } & 4.75 & 94.78 & 0.48 \\
\hline & \multirow{9}{*}{$\stackrel{\frac{\omega}{\sigma}}{\frac{2}{z}}$} & \multirow{9}{*}{ 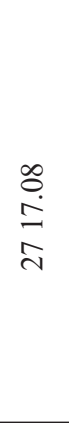 } & \multirow{9}{*}{$\begin{array}{l}\text { ले } \\
\text { ơ } \\
\text { ले }\end{array}$} & I1 & 17.52 & 82.24 & 0.24 \\
\hline & & & & $\mathrm{I} 2$ & 13.28 & 84.74 & 1.99 \\
\hline & & & & I3 & 14.54 & 84.48 & 0.98 \\
\hline & & & & I4 & 19.75 & 80.25 & 0.00 \\
\hline & & & & I5 & 0.41 & 98.52 & 1.08 \\
\hline & & & & I6 & 0.80 & 95.99 & 3.21 \\
\hline & & & & I7 & 15.86 & 83.16 & 0.99 \\
\hline & & & & I8 & 19.06 & 78.08 & 2.86 \\
\hline & & & & I9 & 16.59 & 82.69 & 0.73 \\
\hline & \multicolumn{4}{|c|}{ Mean } & 13.09 & 85.57 & 1.34 \\
\hline
\end{tabular}

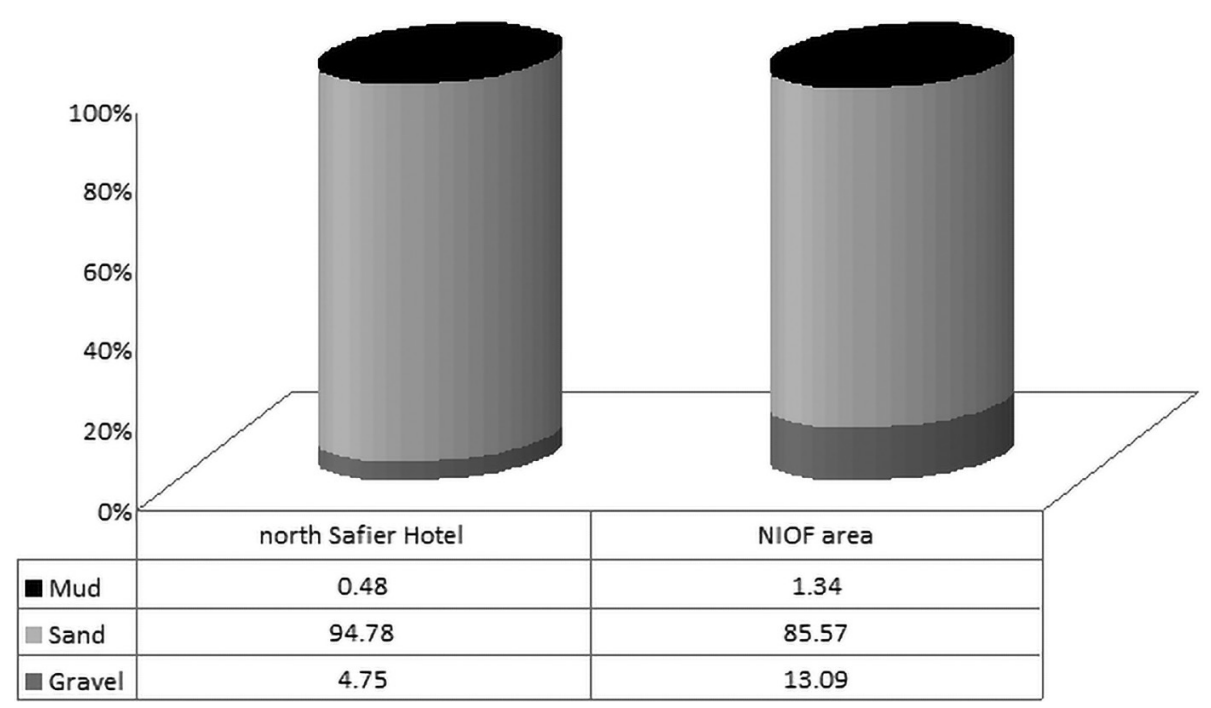

Figure 2: The distribution of gravel, sand and mud fractions in sediment samples (full-coloured illustration are available in the digital version). 
Table 3: The $\mathrm{CaCO}_{3}$ and TOC of samples at the study areas.

\begin{tabular}{|c|c|c|c|c|c|c|}
\hline \multirow{2}{*}{ Area } & \multirow{2}{*}{ Location } & \multicolumn{2}{|c|}{ Position } & \multirow{2}{*}{ Sample code } & \multirow{2}{*}{ Carb. (\%) } & \multirow{2}{*}{ TOC $(\%)$} \\
\hline & & Lat. & Long. & & & \\
\hline \multirow{17}{*}{ 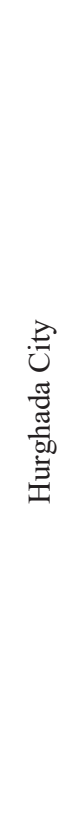 } & \multirow{6}{*}{ 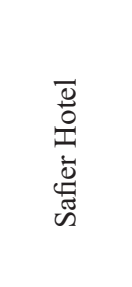 } & \multirow{6}{*}{ 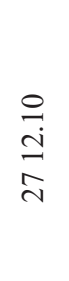 } & \multirow{6}{*}{$\begin{array}{l}\hat{o} \\
\dot{n} \\
\hat{n}\end{array}$} & $\mathrm{H} 1$ & 14.62 & 14.20 \\
\hline & & & & $\mathrm{H} 2$ & 15.92 & 6.90 \\
\hline & & & & $\mathrm{H} 3$ & 16.48 & 10.70 \\
\hline & & & & $\mathrm{H} 4$ & 66.14 & 9.76 \\
\hline & & & & $\mathrm{H} 5$ & 61.84 & 14.40 \\
\hline & & & & H6 & 65.49 & 12.74 \\
\hline & \multicolumn{4}{|c|}{ Mean } & 40.08 & 11.45 \\
\hline & \multirow{10}{*}{$\frac{\sqrt{\circ}}{\mathrm{Z}}$} & \multirow{9}{*}{ 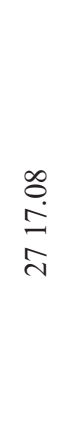 } & \multirow{9}{*}{$\begin{array}{l}\text { ले } \\
\text { రీ } \\
+ \\
\text { mे }\end{array}$} & I1 & 56.32 & 19.08 \\
\hline & & & & $\mathrm{I} 2$ & 60.91 & 32.60 \\
\hline & & & & $\mathrm{I} 3$ & 60.00 & 42.35 \\
\hline & & & & I4 & 35.96 & 30.10 \\
\hline & & & & I5 & 46.60 & 17.67 \\
\hline & & & & I6 & 40.38 & 3.10 \\
\hline & & & & I7 & 47.14 & 4.18 \\
\hline & & & & I8 & 50.18 & 5.00 \\
\hline & & & & I9 & 42.30 & 5.77 \\
\hline & & \multicolumn{3}{|c|}{ Mean } & 48.87 & 17.76 \\
\hline
\end{tabular}

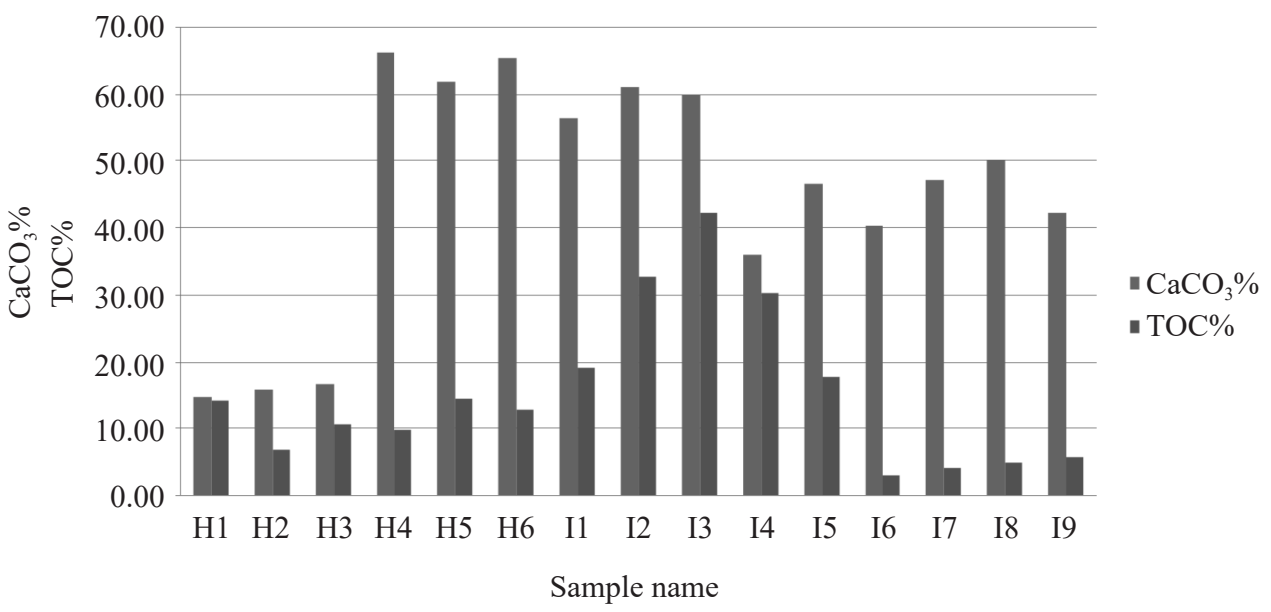

Figure 3: The distribution of $\mathrm{CaCO}_{3}$ content and TOC in sediment samples from Safier Hotel and NIOF (full-coloured illustration are available in the digital version). 


\subsection{Heavy Metals Concentrations}

The concentrations of heavy metals $(\mathrm{Cu}, \mathrm{Zn}, \mathrm{Pb}, \mathrm{Cd}, \mathrm{Fe}, \mathrm{Mn}, \mathrm{Ni}$ and $\mathrm{Co}$ ) were analysed to understand the effect of human action and natural inputs on the quality of marine sediments and to examine the pollution situation. The obtained results are listed in Table 4 and diagrammed in Figures 4 and 5. As shown in Table 4, the major range values of heavy metals concentrations in marine sediment samples were: $\mathrm{Cu}\left(10.5-78.0 \mu \mathrm{g} \mathrm{g}^{-1}\right), \mathrm{Zn}\left(21.0-150.0 \mu \mathrm{g} \mathrm{g}^{-1}\right), \mathrm{Pb}\left(30.0-53.0 \mu \mathrm{g} \mathrm{g}^{-1}\right)$, Cd $\left(2.5-4.0 \mu \mathrm{g} \mathrm{g}^{-1}\right)$, Fe $\left(5100.0-13150.0 \mu \mathrm{g} \mathrm{g}^{-1}\right)$, Mn (118.0-298.0 $\left.\mu \mathrm{g} \mathrm{g}^{-1}\right)$, Ni (17.0-36.0 $\left.\mu \mathrm{g} \mathrm{g}^{-1}\right)$ and $\mathrm{Co}\left(16.0-18.0 \mu \mathrm{g} \mathrm{g}^{-1}\right)$. The highest concentrations of $\mathrm{Cu}$, $\mathrm{Zn}, \mathrm{Cd}$ and Co were found in sediment samples from NIOF area. As expected, the highest concentration of $\mathrm{Pb}, \mathrm{Fe}, \mathrm{Mn}$ and $\mathrm{Ni}$ in samples from Safier Hotel as shown in Figures 4 and 5. The high concentration of iron (Fe) and manganese (Mn) in sediment samples may be due to human activation like sewage, shipment and navigation. ${ }^{30}$

Table 4: Heavy metals concentrations (HMC) in marine sediments of Safier Hotel and NIOF area.

\begin{tabular}{|c|c|c|c|c|c|c|c|c|c|}
\hline \multirow{2}{*}{ Location } & \multirow{2}{*}{ Sample code } & \multicolumn{8}{|c|}{$\mathrm{HMC}$ in $\mu \mathrm{g} \mathrm{g}^{-1}(\mathrm{ppm})$} \\
\hline & & $\mathrm{Cu}$ & $\mathrm{Zn}$ & $\mathrm{Pb}$ & $\mathrm{Cd}$ & $\mathrm{Fe}$ & $\mathrm{Mn}$ & $\mathrm{Ni}$ & Co \\
\hline \multirow[t]{3}{*}{ Safier Hotel } & $\mathrm{H} 1$ & 10.5 & 29.0 & 49.5 & 3.75 & 6700.0 & 118.0 & 17.5 & - \\
\hline & $\mathrm{H} 2$ & 52.0 & 145.0 & 53.0 & 2.50 & 13150.0 & 196.5 & 20.0 & - \\
\hline & H3 & 20.5 & 60.0 & 43.0 & 2.95 & 11700.0 & 298.0 & 36.0 & - \\
\hline \multirow[t]{3}{*}{ NIOF } & I1 & 13.0 & 21.0 & 30.0 & 2.6 & 6000.0 & 135.0 & 17.0 & 18.0 \\
\hline & $\mathrm{I} 2$ & 78.0 & 150.0 & 50.0 & 3.7 & 11800.0 & 200.0 & 25.0 & 18.0 \\
\hline & $\mathrm{I} 3$ & 12.0 & 30.0 & 39.0 & 4.0 & 5100.0 & 160.0 & 20.0 & 16.0 \\
\hline Avg. & & 31.0 & 73.0 & 44.0 & 3.0 & 9075.0 & 185.0 & 23.0 & 17.0 \\
\hline Min. & & 11.0 & 21.0 & 30.0 & 2.5 & 5100.0 & 118.0 & 17.0 & 16.0 \\
\hline Max. & & 78.0 & 150.0 & 53.0 & 4.0 & 13150.0 & 298.0 & 36.0 & 18.0 \\
\hline
\end{tabular}




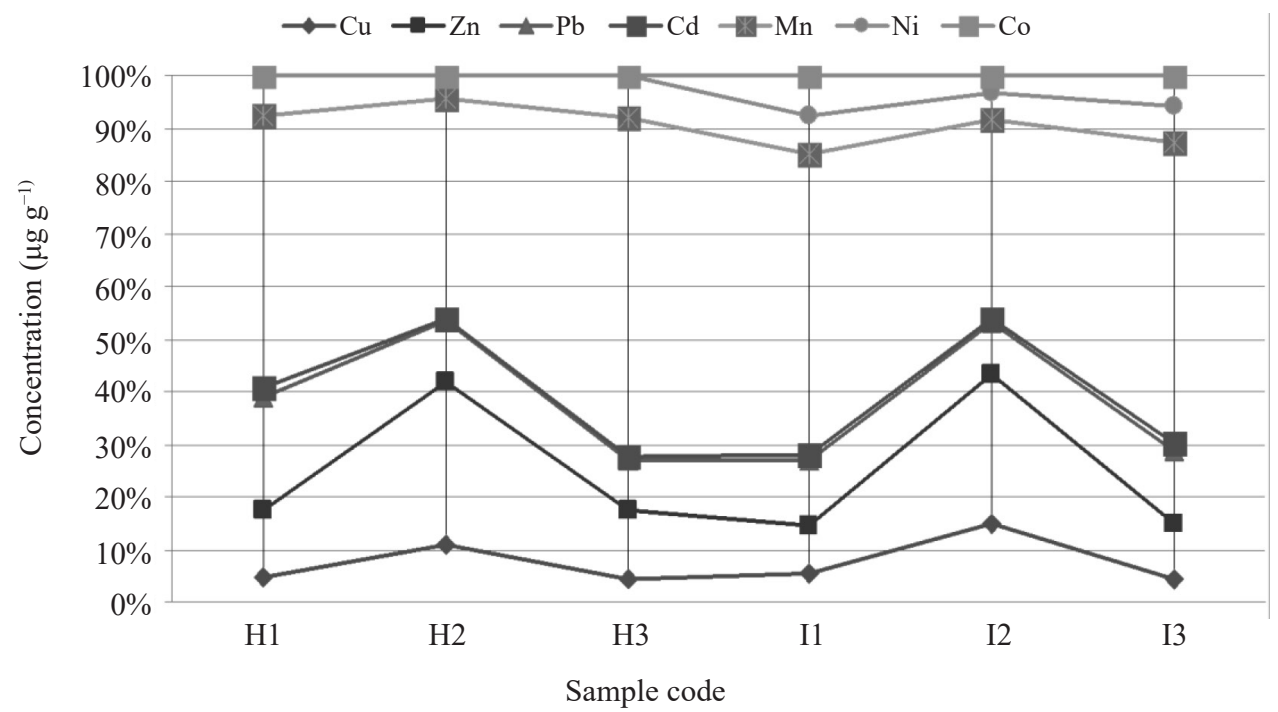

Figure 4. The distribution of heavy metals in sediment samples from Safier Hotel and NIOF area (full-coloured illustration are available in the digital version).

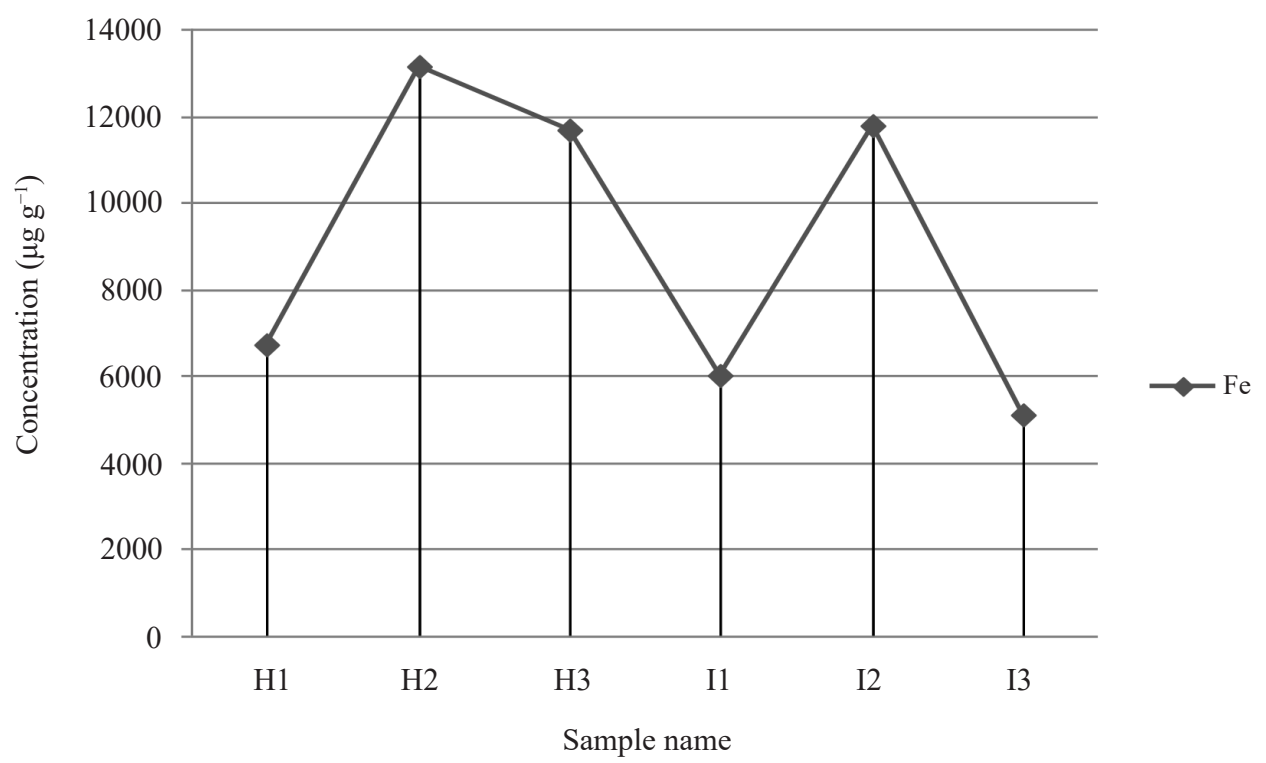

Figure 5: The concentration of iron (Fe) in sediment samples from Safier Hotel and NIOF area. 


\subsection{Activity Concentrations}

The results of measured specific activity as well as the uncertainty of ${ }^{226} \mathrm{Ra}$, ${ }^{232} \mathrm{Th}$ and ${ }^{40} \mathrm{~K}$ of sediment samples were listed in Table 5. From the table, it can be seen that the values of specific activity varied from $7 \pm 1 \mathrm{~Bq} \mathrm{~kg}^{-1}$ to $53 \pm 4 \mathrm{~Bq} \mathrm{~kg}^{-1}, 6 \pm 1 \mathrm{~Bq} \mathrm{~kg}^{-1}$ to $32 \pm 6 \mathrm{~Bq} \mathrm{~kg}^{-1}$ and from $167 \pm 11 \mathrm{~Bq} \mathrm{~kg}^{-1}$ to $1120 \pm 63 \mathrm{~Bq} \mathrm{~kg}{ }^{-1}$ for ${ }^{226} \mathrm{Ra},{ }^{232} \mathrm{Th}$ and ${ }^{40} \mathrm{~K}$, respectively. The variation of radionuclides concentration in studying sediment samples may be due to their presence in the marine environment and their physical, chemical and geo chemical properties..$^{31,32}$

Table 5: Specific activity of ${ }^{226} \mathrm{Ra},{ }^{232} \mathrm{Th}$ and ${ }^{40} \mathrm{~K}$ in marine sediment samples.

\begin{tabular}{|c|c|c|c|c|}
\hline \multirow{2}{*}{ Location } & \multirow{2}{*}{ Sample code } & \multicolumn{3}{|c|}{ Activity $\left(\mathrm{Bq} \mathrm{kg}^{-1}\right)$} \\
\hline & & ${ }^{226} \mathrm{Ra}$ & ${ }^{232} \mathrm{Th}$ & ${ }^{40} \mathrm{~K}$ \\
\hline \multirow{6}{*}{ Safier Hotel } & $\mathrm{H} 1$ & $7 \pm 1$ & $7 \pm 1$ & $167 \pm 11$ \\
\hline & $\mathrm{H} 2$ & $12 \pm 1$ & $10 \pm 2$ & $240 \pm 13$ \\
\hline & H3 & $27 \pm 2$ & $26 \pm 3$ & $431 \pm 24$ \\
\hline & $\mathrm{H} 4$ & $13 \pm 1$ & $22 \pm 3$ & $598 \pm 34$ \\
\hline & H5 & $11 \pm 1$ & $6 \pm 1$ & $323 \pm 20$ \\
\hline & H6 & $10 \pm 1$ & $14 \pm 2$ & $287 \pm 16$ \\
\hline Mean & & $13 \pm 1$ & $14 \pm 2$ & $341 \pm 20$ \\
\hline \multirow{9}{*}{ NIOF } & $\mathrm{I} 1$ & $21 \pm 2$ & $15 \pm 3$ & $384 \pm 22$ \\
\hline & $\mathrm{I} 2$ & $20 \pm 2$ & $21 \pm 4$ & $293 \pm 17$ \\
\hline & I3 & $8 \pm 1$ & $11 \pm 2$ & $247 \pm 14$ \\
\hline & I4 & $39 \pm 3$ & $32 \pm 6$ & $431 \pm 25$ \\
\hline & I5 & $53 \pm 4$ & $14 \pm 2$ & $1120 \pm 63$ \\
\hline & I6 & $15 \pm 1$ & $12 \pm 1$ & $410 \pm 23$ \\
\hline & I7 & $38 \pm 3$ & $30 \pm 3$ & $498 \pm 28$ \\
\hline & I8 & $22 \pm 2$ & $6 \pm 1$ & $376 \pm 21$ \\
\hline & I9 & $22 \pm 2$ & $16 \pm 3$ & $329 \pm 19$ \\
\hline Mean & & $27 \pm 2$ & $17 \pm 3$ & $454 \pm 26$ \\
\hline
\end{tabular}

The highest mean value of ${ }^{226} \mathrm{Ra},{ }^{232} \mathrm{Th}$ and ${ }^{40} \mathrm{~K}$ specific activity are found in samples from NIOF area as shown in Figure 6. This may be due to the terrestrial deposits transported from the fringing mountains to the beaches of the Red Sea, where uranium concentration in the shore sediment depends on the uranium concentration in the fringing mountains. ${ }^{33}$ The mean concentrations of ${ }^{226} \mathrm{Ra}$ and ${ }^{232} \mathrm{Th}$ were lower than the permissible activity levels which are $35 \mathrm{~Bq} \mathrm{~kg}^{-1}$, 
$35 \mathrm{~Bq} \mathrm{~kg}^{-1}$ and $400 \mathrm{~Bq} \mathrm{~kg}{ }^{-1}$ respectively for ${ }^{226} \mathrm{Ra},{ }^{232} \mathrm{Th}$ and ${ }^{40} \mathrm{~K}$, while the mean concentrations of ${ }^{40} \mathrm{~K}$ were higher than the permissible activity levels in samples from NIOF area and lower than in samples from Safier Hotel. ${ }^{3}$ Figure 7 shows good correlation $\left(\mathrm{R}^{2}=0.62\right)$ between activity concentration of ${ }^{40} \mathrm{~K}$ and ${ }^{226} \mathrm{Ra}$. The correlation indicates that the ${ }^{40} \mathrm{~K}$ and ${ }^{226} \mathrm{Ra}$ is representative of a common geological origin. Figure 7 also shows a weak correlation between ${ }^{226} \mathrm{Ra}$ and ${ }^{232} \mathrm{Th}\left(\mathrm{R}^{2}=0.31\right)$ and a poor correlation between ${ }^{232} \mathrm{Th}$ and ${ }^{40} \mathrm{~K}\left(\mathrm{R}^{2}=0.06\right)$, which indicates that ${ }^{40} \mathrm{~K}$ concentrations are not related to the presence of ${ }^{232} \mathrm{Th}$ in samples.

Also, the value of ${ }^{232} \mathrm{Th} /{ }^{226} \mathrm{Ra},{ }^{232} \mathrm{Th} /{ }^{40} \mathrm{~K}$ and ${ }^{226} \mathrm{Ra} /{ }^{40} \mathrm{~K}$ ratios in all measured samples were listed in Table 6. From the obtained results, it is evident that the average values of ${ }^{232} \mathrm{Th} /{ }^{226} \mathrm{Ra},{ }^{232} \mathrm{Th} /{ }^{40} \mathrm{~K}$ and ${ }^{226} \mathrm{Ra} /{ }^{/ 0} \mathrm{~K}$ ratios are $1.078,0.041$ and 0.040 in samples from Safier Hotel, while the average ratios in samples from NIOF area are $0.745,0.044$ and 0.060 , respectively.

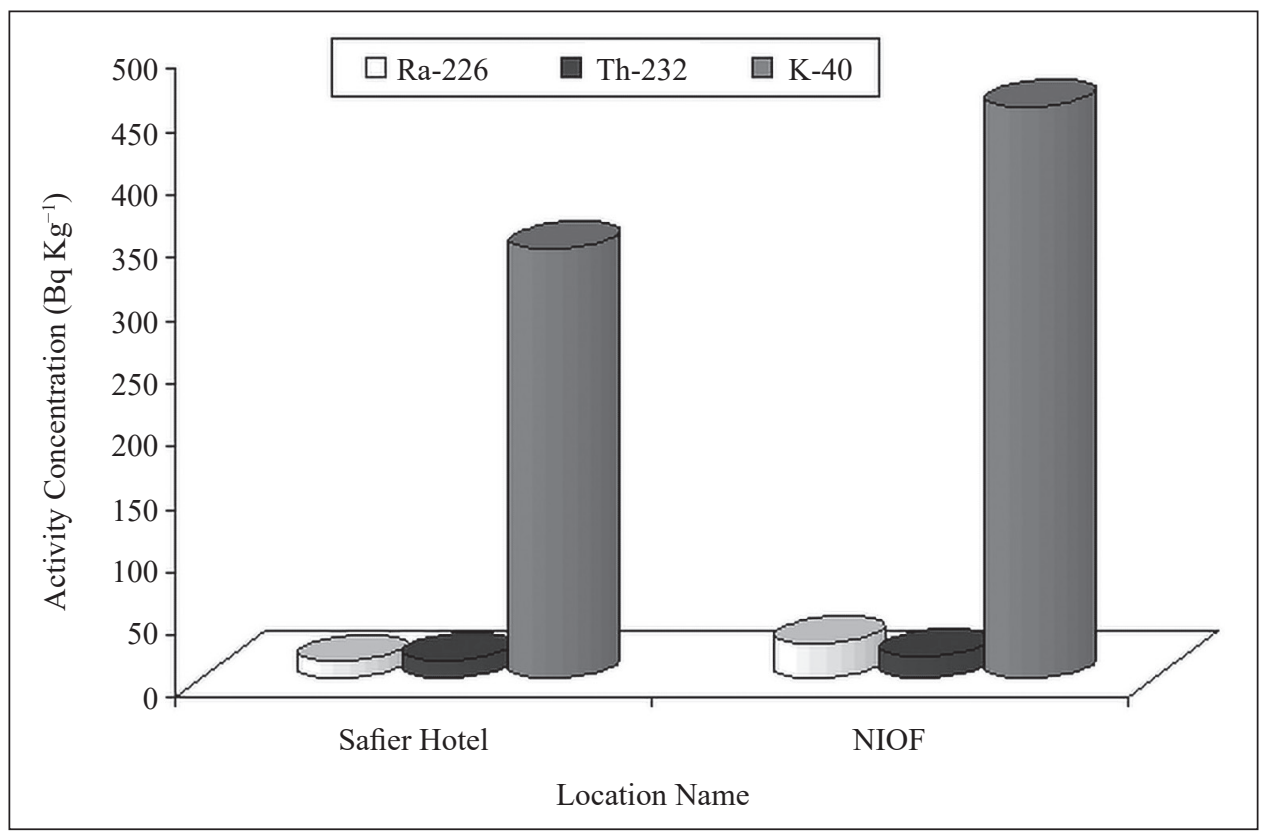

Figure 6: Average values of ${ }^{226} \mathrm{Ra},{ }^{232} \mathrm{Th}$ and ${ }^{40} \mathrm{~K}$ specific activity in samples from Safier Hotel and NIOF area. 

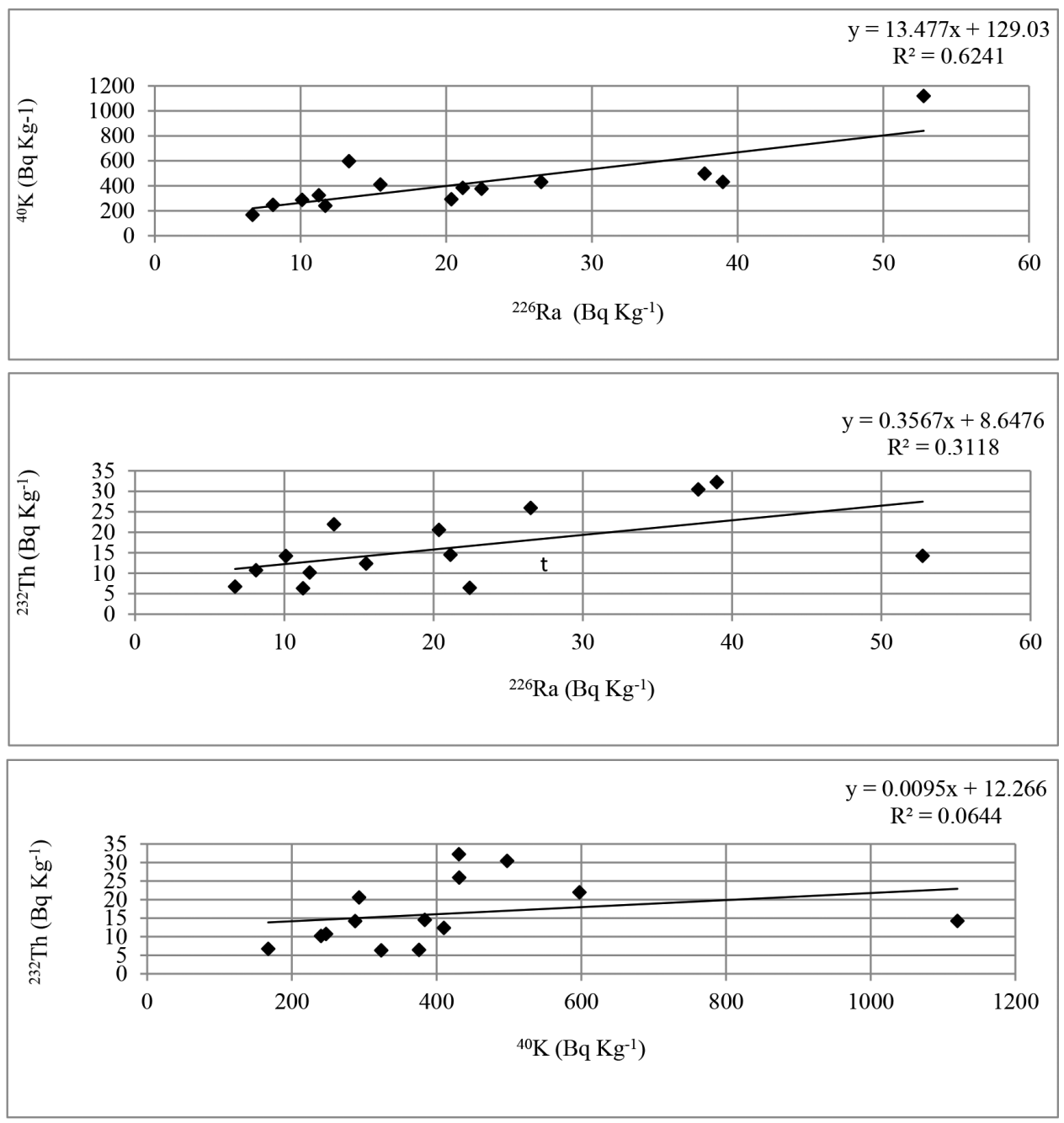

Figure 7: The correlation between activity concentrations of ${ }^{226} \mathrm{Ra},{ }^{232} \mathrm{Th}$ and ${ }^{40} \mathrm{~K}$ in samples from Safier Hotel and NIOF area. 
Table 6: Activity ratios between natural radionuclides of sediment samples at the study areas.

\begin{tabular}{cccc}
\hline Sample code & ${ }^{232} \mathrm{Th} /{ }^{226} \mathrm{Ra}$ & ${ }^{232} \mathrm{Th} /{ }^{40} \mathrm{~K}$ & ${ }^{226} \mathrm{Ra} /{ }^{40} \mathrm{~K}$ \\
\hline H1 & 1.004 & 0.040 & 0.040 \\
H2 & 0.870 & 0.042 & 0.049 \\
H3 & 0.979 & 0.060 & 0.061 \\
H4 & 1.646 & 0.037 & 0.022 \\
H5 & 0.561 & 0.020 & 0.035 \\
H6 & 1.405 & 0.049 & 0.035 \\
\hline Mean & 1.078 & 0.041 & 0.040 \\
\hline I1 & 0.687 & 0.038 & 0.055 \\
I2 & 1.010 & 0.070 & 0.070 \\
I3 & 1.324 & 0.043 & 0.033 \\
I4 & 0.827 & 0.075 & 0.091 \\
I5 & 0.270 & 0.013 & 0.047 \\
I6 & 0.799 & 0.030 & 0.038 \\
I7 & 0.807 & 0.061 & 0.076 \\
I8 & 0.286 & 0.017 & 0.060 \\
I9 & 0.695 & 0.047 & 0.068 \\
\hline Mean & 0.745 & 0.044 & 0.060 \\
\hline
\end{tabular}

\subsection{Statistical Analysis}

\subsubsection{Histograms}

The frequency distributions of the radionuclides in sediment samples from Safier Hotel and NIOF area were analysed by SPSS19 and histograms are given in Figures 8 to 10 . A histogram is a graphical representation of the distribution of data. It is an estimate of the probability distribution of continuous variables. The graph of ${ }^{232} \mathrm{Th}$ for sediment samples from Safier Hotel and NIOF area shows that these radionuclides demonstrate a normal (bell-shape) distribution as shown in Figure 9. But the graphs of ${ }^{226} \mathrm{Ra}$ and ${ }^{40} \mathrm{~K}$ show that the radionuclides exhibited some degree of multi-modality. This multi-modal feature of the radio-elements demonstrates the complexity of sediments samples as shown in Figures 8 and 10. 


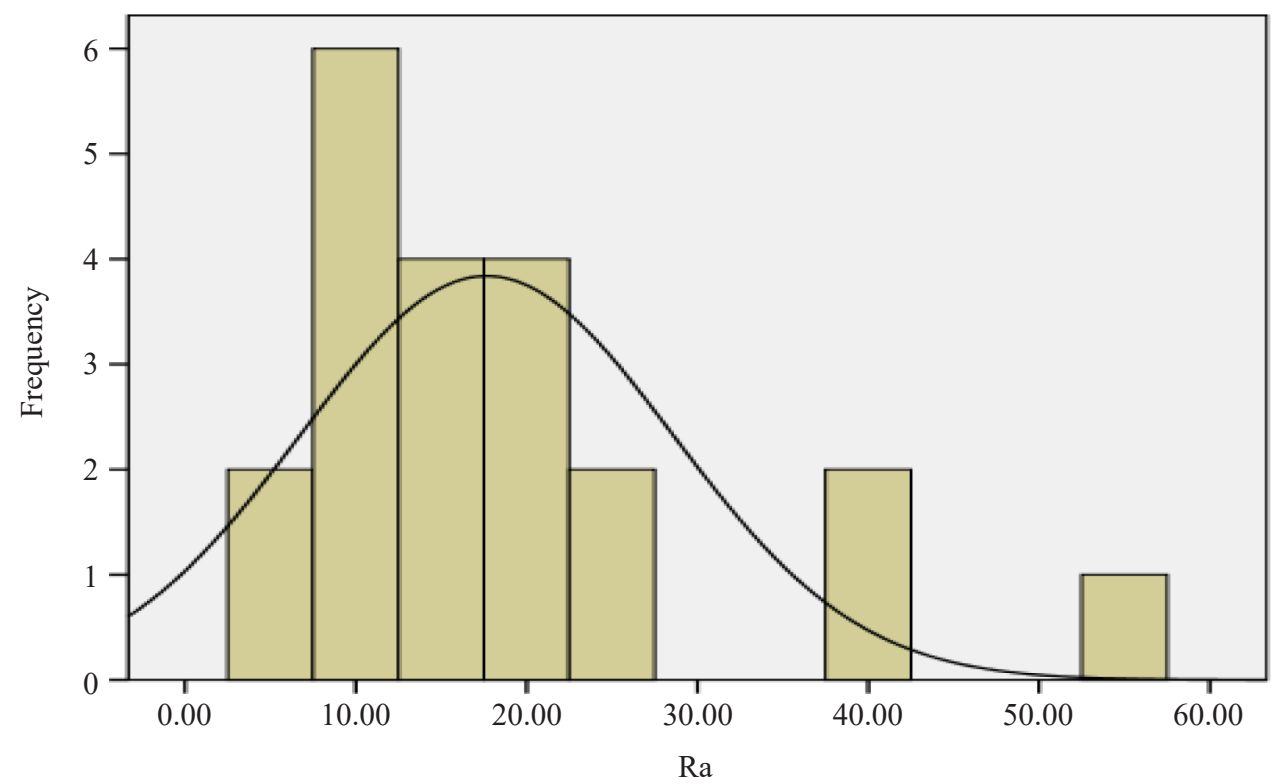

Figure 8: The frequency distributions of ${ }^{226} \mathrm{Ra}$ found in samples from Safier Hotel and NIOF area.

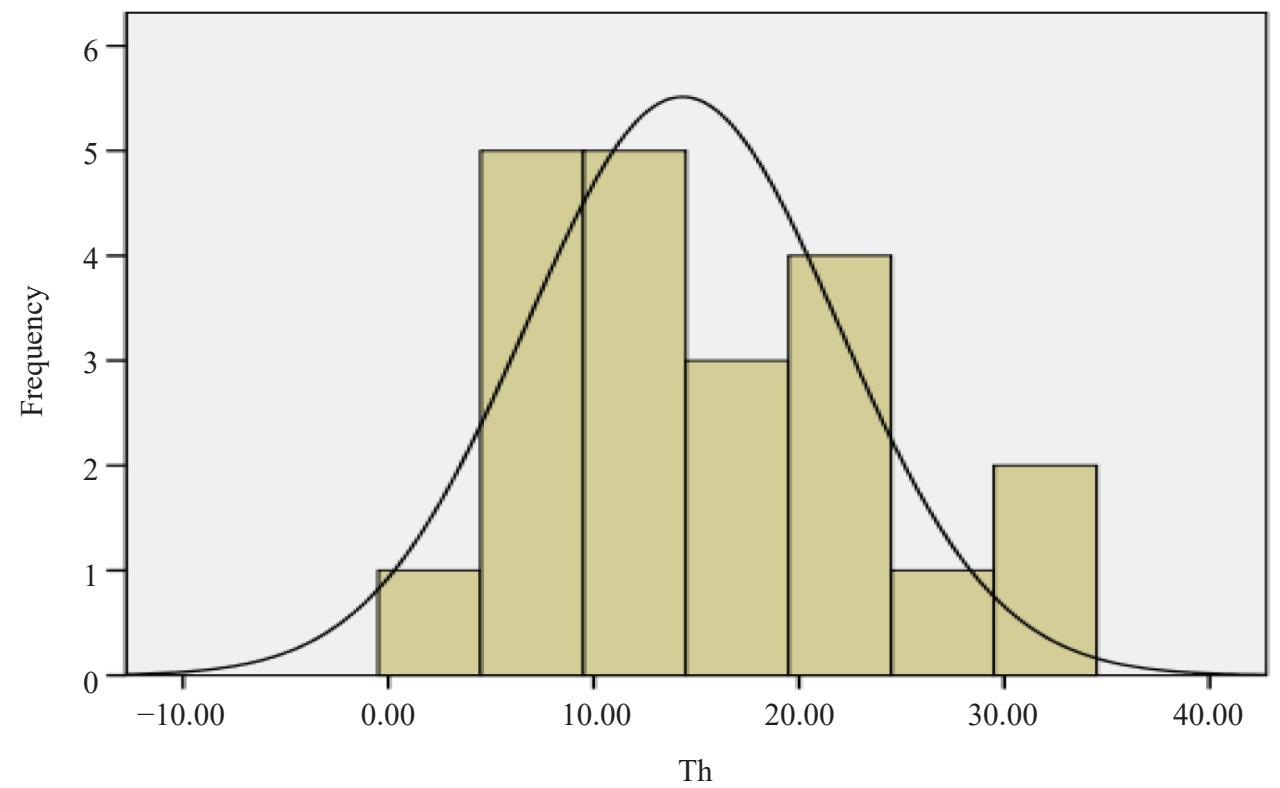

Figure 9: The frequency distributions of ${ }^{232} \mathrm{Th}$ found in samples from Safier Hotel and NIOF area. 


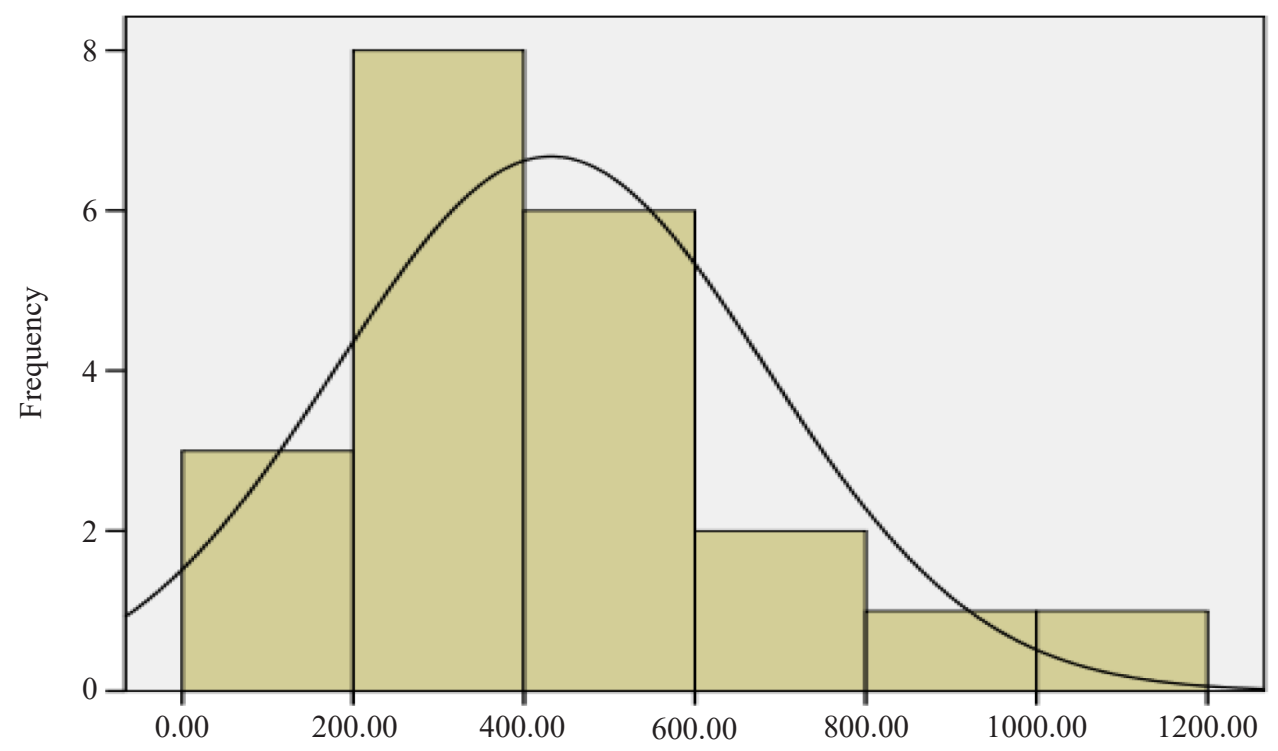

Figure 10: Frequency distributions of ${ }^{40} \mathrm{~K}$ found in samples from Safier Hotel and NIOF area.

\subsection{Comparison of Specific Activity Studied in Other Countries}

The specific activity of ${ }^{226} \mathrm{Ra},{ }^{232} \mathrm{Th}$ and ${ }^{40} \mathrm{~K}$ in sediment samples from the studied areas were compared with those from similar investigations in other countries and presented in Table 7. It can be seen from Table 7 that the mean values of ${ }^{226} \mathrm{Ra}$, ${ }^{232} \mathrm{Th}$ and ${ }^{40} \mathrm{~K}$ in sediment samples were in the range or less than the corresponding values in the listed countries.

\subsection{Radiological Hazards Indices of Investigated Samples}

$\mathrm{Ra}_{\text {eq }}, \mathrm{D}, \mathrm{H}_{\mathrm{ex}}, \mathrm{H}_{\text {in }}, \mathrm{I}_{\gamma}$, AED and ELCR were estimated using Equations 3 to 9 and their results are presented in Tables 8 and 9. From Table 8 , it is observed that the values of radium equivalent in sediment samples are lower than the allowed maximum value of $370 \mathrm{~Bq} \mathrm{~kg}$, and fluctuate from $29 \mathrm{~Bq} \mathrm{~kg}^{-1}$ to $159 \mathrm{~Bq} \mathrm{~kg}^{-1}$. Figure 11 shows the distribution of $\mathrm{Ra}_{\mathrm{eq}}$ in samples from NIOF area and Safier Hotel. ${ }^{22}$ As listed in Table 8, the mean value of dose rates in sediment samples is lower than the international limit $59 \mathrm{nGyh}^{-1}$. The average annual effective dose rates vary from $35.2 \mu \mathrm{Svy}^{-1}$ (Safier Hotel) to $51.0 \mu \mathrm{Svy}^{-1}$ (NIOF), which are lower than the world average values at $70.0 \mu \mathrm{Sv}$ year $^{-1}$. Figure 12 shows the distribution of AED in samples from NIOF area and Safier Hotel. ${ }^{26}$ 
Table 7: Average specific activity of ${ }^{226} \mathrm{Ra},{ }^{232} \mathrm{Th}$ and ${ }^{40} \mathrm{~K}$ for all sediment samples under investigation beside other countries.

\begin{tabular}{|c|c|c|c|}
\hline \multirow{2}{*}{ Country } & \multicolumn{3}{|c|}{ Activity $\left(\mathrm{Bq} \mathrm{kg}^{-1}\right)$} \\
\hline & ${ }^{226} \mathrm{Ra}$ & ${ }^{232} \mathrm{Th}$ & ${ }^{40} \mathrm{~K}$ \\
\hline Egypt (Safier Hotel) (Present work) & $13 \pm 1$ & $14 \pm 2$ & $341 \pm 20$ \\
\hline Egypt (NIOF area) (Present work) & $27 \pm 2$ & $17 \pm 3$ & $454 \pm 26$ \\
\hline Egypt (Brullus Lake) $)^{34}$ & 14 & 20 & 312 \\
\hline Egypt (Red Sea Wadies) ${ }^{35}$ & 27 & 38 & 419 \\
\hline Egypt (River Nile sediments $)^{36}$ & $(3.8-34.9)$ & $(2.9-30.1)$ & $(112-313)$ \\
\hline Jordon (Gulf Aqaba, Red Sea) ${ }^{37}$ & $734 \pm 19$ & $734 \pm 19$ & $734 \pm 19$ \\
\hline Egypt (El-Hamraween SS) ${ }^{38}$ & $29 \pm 0.4$ & $8 \pm 0.1$ & $282 \pm 7$ \\
\hline Egypt El-Hamraween BS) ${ }^{38}$ & $238 \pm 4$ & $11 \pm 0.3$ & $195 \pm 7$ \\
\hline Egypt (Ras El Behar SS) ${ }^{38}$ & $14 \pm 0.3$ & $13 \pm 0.3$ & $396 \pm 12$ \\
\hline Egypt (Ras El Behar BS) $)^{38}$ & $16 \pm 0.4$ & $19 \pm 0.4$ & $266 \pm 10$ \\
\hline Egypt (Safaga sand) ${ }^{39}$ & $25.3 \pm 13.7$ & $21.4 \pm 10$ & $618 \pm 122$ \\
\hline Sudan Red Sea Coastal $)^{40}$ & 11.6 & 6.02 & 158.4 \\
\hline Egypt (Red Sea shore sediment) ${ }^{33}$ & $24.7 \pm 4.3$ & $31.4 \pm 9.6$ & $427.5 \pm 35$ \\
\hline Egypt (Nasser Lake) ${ }^{40}$ & $222-326$ & $222-326$ & $222-326$ \\
\hline Egypt (Suez Canal) ${ }^{41}$ & $4.9-20.2$ & $3.3-35.4$ & $59-368$ \\
\hline Saudi Arabia (Ras Tanura) ${ }^{11}$ & $11.68 \pm 1.22$ & $6.21 \pm 0.58$ & $169.40 \pm 7$ \\
\hline Denmark (Beach sediment) ${ }^{14}$ & 17 & 19 & 460 \\
\hline Spain $((\text { Beach sediment }))^{14}$ & 32 & 33 & 470 \\
\hline Hong Kong (Beach sediment) ${ }^{14}$ & 59 & 95 & 530 \\
\hline
\end{tabular}

Table 8: $\mathrm{Ra}_{\mathrm{eq}}$, $\mathrm{D}$ and AED for the studied samples.

\begin{tabular}{lcccc}
\hline \multirow{2}{*}{ Location } & Sample code & $\mathrm{Ra}_{\mathrm{eq}}$ & $\mathrm{D}$ & $\mathrm{AED}$ \\
\cline { 3 - 5 } & & $\left(\mathrm{Bq} \mathrm{kg}^{-1}\right)$ & $\left(\mathrm{nGy} \mathrm{h}^{-1}\right)$ & $\left(\mu \mathrm{Sv} \mathrm{y}^{-1}\right)$ \\
\hline \multirow{4}{*}{ Safier Hotel } & 29 & 14 & 17 \\
& $\mathrm{H} 2$ & 45 & 21 & 26 \\
& $\mathrm{H} 3$ & 97 & 46 & 56 \\
& $\mathrm{H} 4$ & 91 & 44 & 54 \\
& $\mathrm{H} 5$ & 45 & 22 & 27 \\
\hline & $\mathrm{H} 6$ & 53 & 25 & 31 \\
\hline
\end{tabular}


Table 8: (Continued)

\begin{tabular}{ccccc}
\hline \multirow{2}{*}{ Location } & Sample code & $\mathrm{Ra}_{\mathrm{eq}}$ & $\mathrm{D}$ & $\mathrm{AED}$ \\
\cline { 3 - 5 } & & $\left(\mathrm{Bq} \mathrm{kg}^{-1}\right)$ & $\left(\mathrm{nGy} \mathrm{h}^{-1}\right)$ & $\left(\mu \mathrm{Sv} \mathrm{y}^{-1}\right)$ \\
\hline \multirow{4}{*}{ NIOF } & I1 & 71 & 34 & 42 \\
& $\mathrm{I} 2$ & 72 & 34 & 42 \\
& $\mathrm{I} 3$ & 42 & 20 & 25 \\
& $\mathrm{I} 4$ & 118 & 55 & 68 \\
& $\mathrm{I} 5$ & 159 & 79 & 97 \\
$\mathrm{I} 6$ & 65 & 31 & 39 \\
& $\mathrm{I} 7$ & 120 & 56 & 69 \\
$\mathrm{I}$ & 61 & 30 & 36 \\
& $\mathrm{I} 9$ & 70 & 33 & 41 \\
\hline
\end{tabular}

Table 9 shows that the $\mathrm{H}_{\mathrm{ex}}$ and $\mathrm{H}_{\text {in }}$ values resulting from all samples are lower than the unity, which do not cause any harm to the populations in all regions under investigation. ${ }^{14}$ The calculated $\mathrm{I}_{\gamma}$ values for the samples under investigation are given in Table 9. It is clear that the sediment samples are lower than unity. ${ }^{14}$

Table 9: $H_{e x}, H_{i n}, I_{\gamma}$ and ELCR for the studied samples.

\begin{tabular}{|c|c|c|c|c|c|}
\hline Location & Sample code & $\mathrm{H}_{\mathrm{ex}}$ & $\mathrm{H}_{\text {in }}$ & $\mathrm{I}_{\gamma}$ & $\mathrm{ELCR} \times 10^{-6}$ \\
\hline \multirow{7}{*}{ Safier Hotel } & H1 & 0.1 & 0.1 & 0.1 & 60 \\
\hline & $\mathrm{H} 2$ & 0.1 & 0.2 & 0.1 & 92 \\
\hline & H3 & 0.3 & 0.3 & 0.3 & 196 \\
\hline & $\mathrm{H} 4$ & 0.2 & 0.3 & 0.3 & 189 \\
\hline & H5 & 0.1 & 0.2 & 0.2 & 96 \\
\hline & H6 & 0.1 & 0.2 & 0.2 & 107 \\
\hline & Mean & 0.2 & 0.2 & 0.2 & 123.3 \\
\hline \multirow{10}{*}{ NIOF } & I1 & 0.2 & 0.3 & 0.2 & 147 \\
\hline & $\mathrm{I} 2$ & 0.2 & 0.3 & 0.2 & 145 \\
\hline & I3 & 0.1 & 0.1 & 0.1 & 87 \\
\hline & I4 & 0.3 & 0.4 & 0.4 & 237 \\
\hline & I5 & 0.4 & 0.6 & 0.5 & 339 \\
\hline & I6 & 0.2 & 0.2 & 0.2 & 135 \\
\hline & I7 & 0.3 & 0.4 & 0.4 & 241 \\
\hline & I8 & 0.2 & 0.2 & 0.2 & 127 \\
\hline & I9 & 0.2 & 0.2 & 0.2 & 143 \\
\hline & Mean & 0.23 & 0.30 & 0.27 & 177.89 \\
\hline
\end{tabular}


Finally, Table 9 gives the results for ELCR for samples, the highest average value is $339 \times 10^{-6}$ for marine sediment samples from NIOF, while the lowest average value is $60 \times 10^{-6}$ for samples from Safire Hotel. These values are lower than the worldwide recommended value of $0.29 \times 10^{-3}$. Figure 13 shows the distribution of ELCR in samples from NIOF area and Safier Hotel.
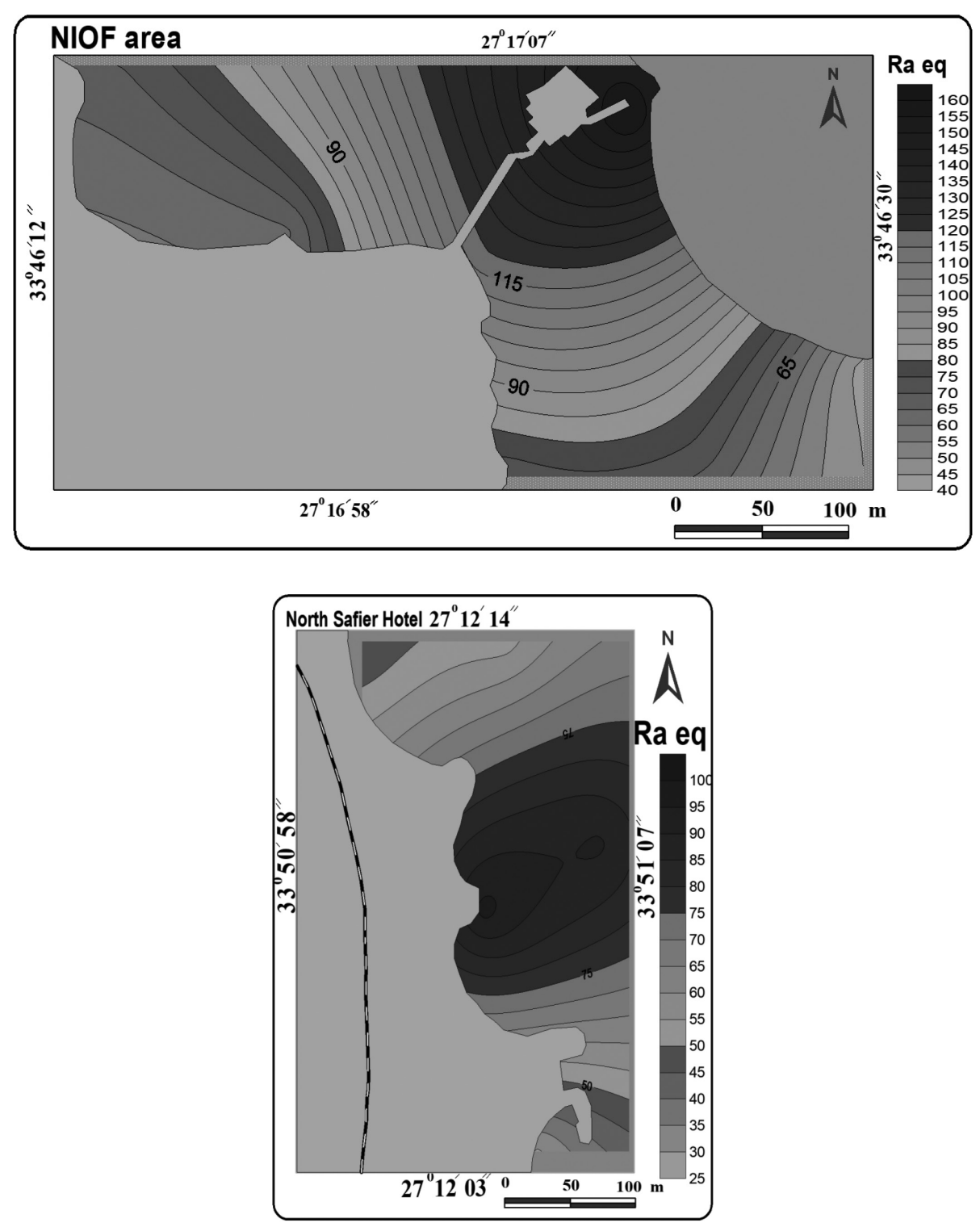

Figure 11: The distribution of $\mathrm{Ra}_{\mathrm{eq}}$ in sediment samples (full-coloured illustrations are available in the digital version). 

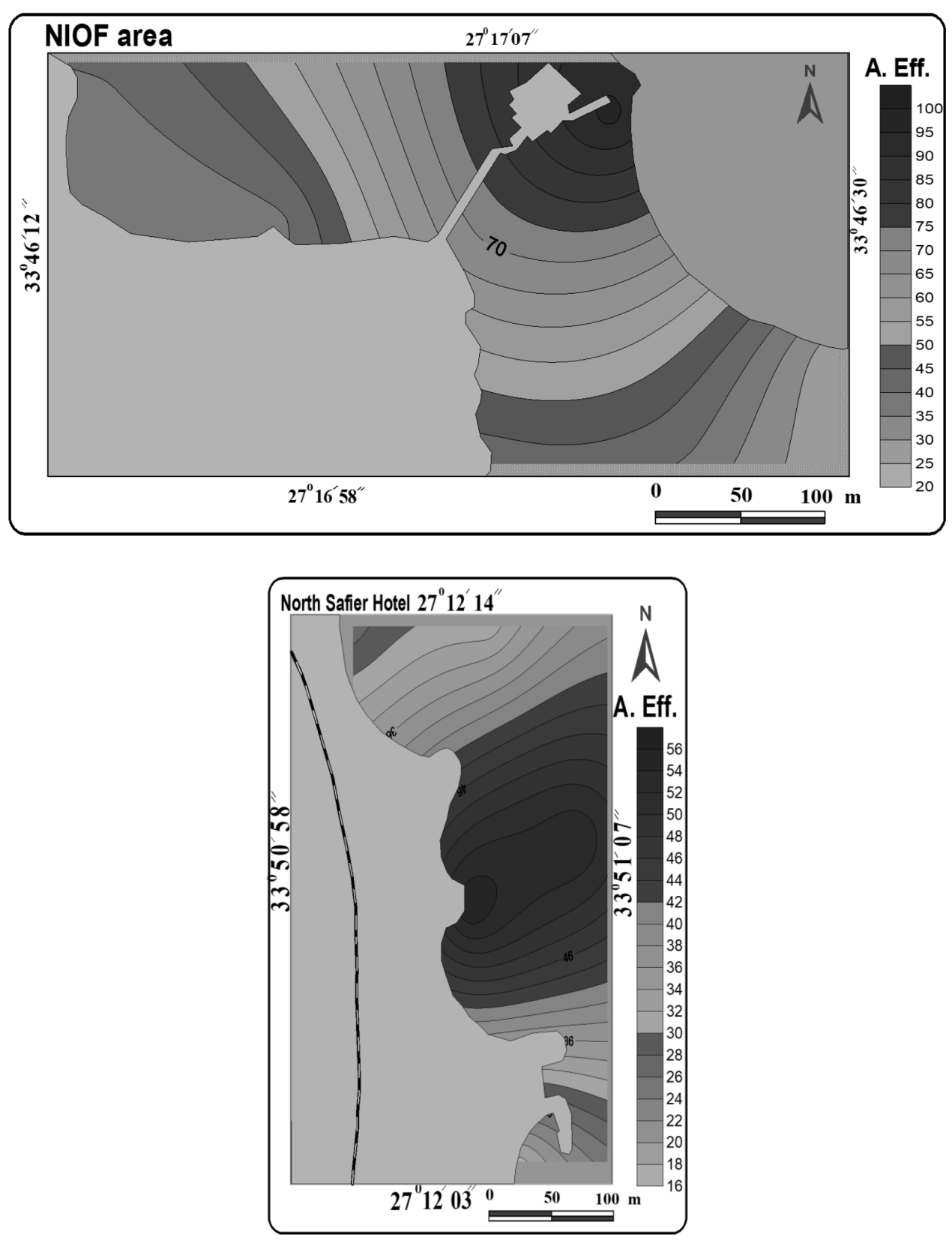

Figure 12: The distribution of AED in sediment samples (full-coloured illustrations are available in the digital version). 

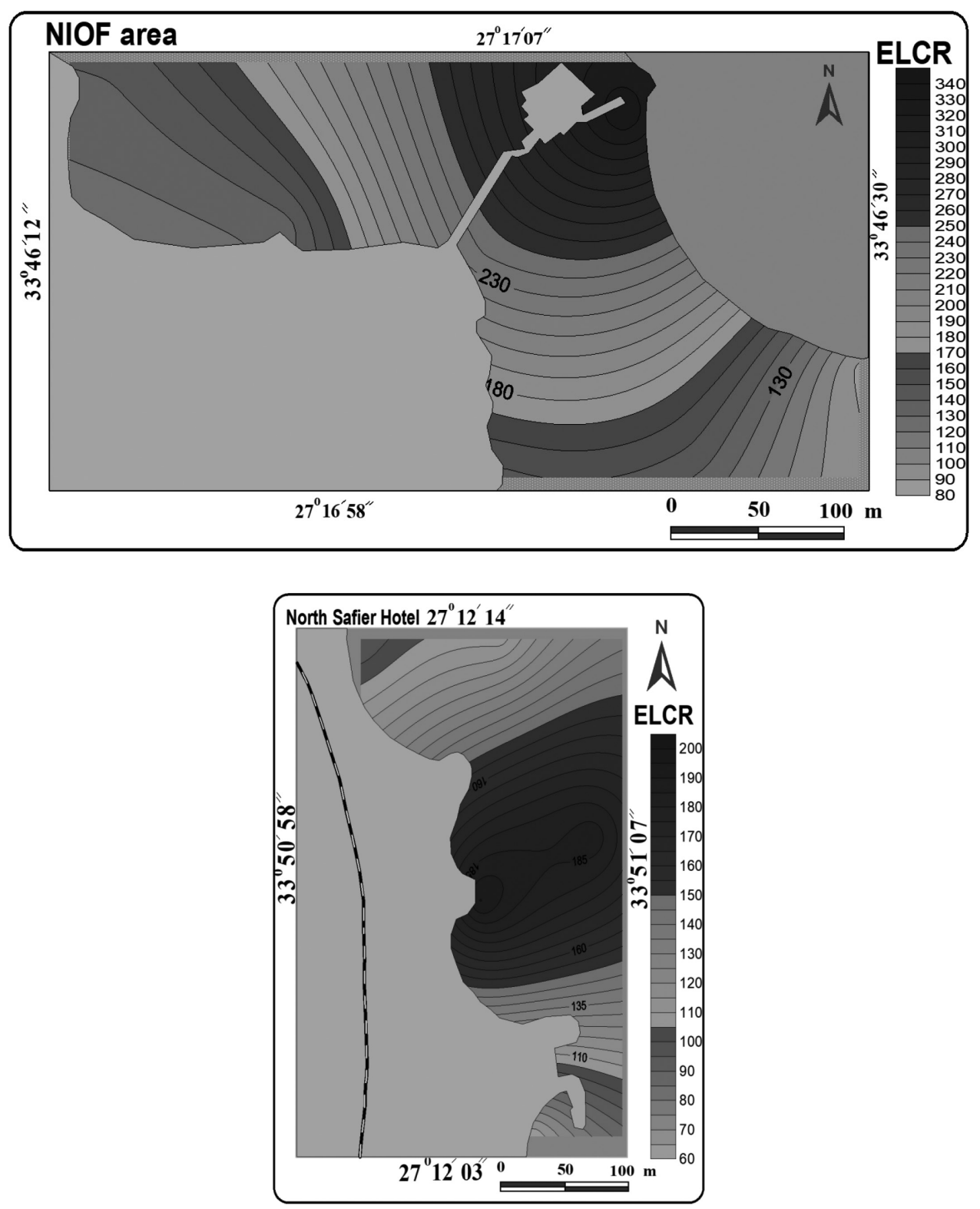

Figure 13: The distribution of ELCR in sediment samples (full-coloured illustrations are available in the digital version). 


\section{CONCLUSION}

The specific activity of ${ }^{40} \mathrm{~K},{ }^{232} \mathrm{Th}$ and ${ }^{226} \mathrm{Ra}$ in marine sediment samples collected from NIOF and Safier Hotel area in Hurghada city, Egypt were measured. The concentrations of ${ }^{226} \mathrm{Ra}$ and ${ }^{232} \mathrm{Th}$ were lower than the permissible activity levels which are $35 \mathrm{~Bq} \mathrm{~kg}^{-1}$ and $35 \mathrm{~Bq} \mathrm{~kg}^{-1}$, respectively, whereas concentration of ${ }^{40} \mathrm{~K}$ at $400 \mathrm{~Bq} \mathrm{~kg}^{-1}$ was higher than the permissible activity levels in samples from NIOF area and lower than samples from Safier Hotel. The highest concentrations of $\mathrm{Cu}$, $\mathrm{Zn}, \mathrm{Cd}$ and $\mathrm{Co}$ were found in sediment samples from NIOF area. As expected, the highest concentration of $\mathrm{Pb}, \mathrm{Fe}, \mathrm{Mn}$ and $\mathrm{Ni}$ are obtained in samples from Safier Hotel area. All measured radiological hazards are less than permissible limit. Hence harmful radiation effects are not posed to the public going to NIOF, tourists going to Safier Hotel for recreation, or to the sailors and fishermen involved in their activities in the area as a result of the natural radioactivity of beach sediments. The data obtained in this study may be useful for natural radioactivity mapping and also used as a reference data for monitoring possible radioactivity pollution in future.

\section{REFERENCES}

1. El-Taher, A., Zakaly, H. M. H. \& Elsaman, R. (2018). Environmental implications and spatial distribution of natural radionuclides and heavy metals in sediments from four harbours in the Egyptian Red Sea coast. App. Radiat. Isot., 131, 13-22, https://doi.org/10.1016/j.apradiso.2017.09.024.

2. Madkour, H. A., Abdelhalim, M. A. \& El-Taher, A. (2013). Assessment of heavy metals concentrations resulting natural inputs in Wadi El-Gemal surface sediments, Red Sea coast. Life Sci. J., 10(4), 686-694.

3. United Nations Scientific Committee on the Effects of Atomic Radiation, UNSCEAR. (1993). United Nations Scientific Committee on the effects of atomic sources and effects of ionizing radiation. Report to General Assembly, with Scientific Annexes, New York.

4. Abdel Halim, M. A. K. \& El-Taher, A. (2014). Elemental analysis of limestone by using instrumental neutron activation analysis. J. Radioanal. Nucl. Chem., 299, 1949-1953, https://doi.org/10.1007/s10967-014-2925-4.

5. Suresh, G. et al. (2011). Relationship between the natural radioactivity and mineralogical composition of the Ponnaiyar river sediments, India. J. Environ. Radioact., 102, 370-377, https://doi.org/10.1016/j.jenvrad.2011.02.003.

6. El-Taher, A. \& Madkour, H. A. (2014). Environmental and radio-ecological studies on shallow marine sediments from harbour areas along the Red Sea coast of Egypt for identification of anthropogenic impacts. Isot. Environ. Health Stud., 50, 120-133, https://doi.org/10.1080/ 10256016.2013. 826211. 
7. El-Kameesy, S. U. et al. (2008). Natural radioactivity of beach sand samples in the Tripoli Region, Northwest Libya. Turk. J. Eng. Env. Sci., 32, 245-251.

8. El-Taher, A. (2010). Determination of chromium and trace elements in El-Rubshi chromite from Eastern desert Egypt by neutron activation analysis. App. Radiat. Isot., 68(9), 1864-1868, https://doi.org/10.1016/j.apradiso.2010.04.018.

9. El-Taher, A. (2010). Elemental content of feldspar from Eastern Desert, Egypt, determined by INAA and XRF. App. Radiat. Isot., 68(6), 1185-1188, https://doi. org/10.1016/j.apradiso.2010.02.002.

10. Khan, M. Z. H. et al. (2017). Distribution of heavy metals in surface sediments of the Bay of Bengal Coast. J. Toxicol., Article ID 9235764, https://doi. org/10.1155/2017/9235764.

11. El-Taher, A., Alshahri, F. \& Elsaman, R. (2018). Environmental impacts of heavy metals, rare earth elements and natural radionuclides in marine sediment from Ras Tanura, Saudi Arabia along the Arabian Gulf. Appl. Radiat. Isot., 132, 95-104, https://doi.org/10.1016/j.apradiso.2017.11.022.

12. El-Taher, A. (2012). Elemental analysis of granite by instrumental neutron activation analysis (INAA) and X-ray fluorescence analysis (XRF). J. Appl. Radiat. Isot., 70, 350-354, https://doi.org/10.1016/j.apradiso.2011.09.008.

13. Madkour, H. A. et al. (2012). Contamination of coastal sediments in ElHamrawein Harbour, Red Sea Egypt. J. Environ. Sci. Tech., 5(4), 210-221, https://doi.org/10.3923/jest.2012.210.221.

14. UNSCEAR. (2000). Sources and effects of ionizing radiation. Report to the General Assembly, United Nations New York.

15. El-Taher, A. (2012). Assessment of natural radioactivity levels and radiation hazards for building materials used in Qassim area, Saudi Arabia. Rom. J. Phys., 57, 726-735.

16. El-Taher, A. (2011). Terrestrial gamma radioactivity levels and their corresponding extent exposure of environmental samples from Wadi El Assuity protective area, Assuit, Upper Egypt. J. Rad. Protect. Dosim., 145(4), 405-410.

17. GENIE-2000. (1997). Basic spectroscopy (standalone) V1.2A. Meriden, CT: Canberra Industries.

18. Mahmoud, H. M. et al. (2005). Multi-element determination of sandstone rock by instrumental neutron activation analysis. J. Radioanal. Nucl. Chem., 264(3), $715-718$.

19. Makhluf, S. \& El-Taher, A. (2010). Natural radioactivity levels in phosphate fertilizer and its environmental implications in Assuit governorate, Upper Egypt. Ind. J. Pure Aappl. Phys., 48, 697-702.

20. Althoyaib, S. S. \& El-Taher, A. (2012). Natural radioactivity levels and heavy metals in chemical and organic fertilizer used in Kingdom of Saudi Arabia. Appl. Radiat. Isot., 70 (1), 290-295, https://doi.org/10.1016/j.apradiso.2011.08.010.

21. Mohanty, A. K. et al. (2004). Natural radioactivity and radiation exposure in the high background area at Chhatrapur beach placer deposit of Orissa, India. J. Environ. Radioact., 75, 15-33, https://doi.org/10.1016/j.jenvrad.2003.09.004. 
22. Camacho, A. et al. (2010). Distribution of uranium isotopes in surface water of the lobregat river basin (Northeast Spain). J. Environ. Radioact., 101(12), 1048-1054, https://doi.org/10.1016/j.jenvrad.2010.08.005.

23. Hayambu, P. et al. (1995). Natural radioactivity in Zambian building materials collected from Lusaka. J. Radioanal. Nucl. Chem., 199(3), 229-238.

24. Ramaswamy, V. et al. (2011). Horizontal and vertical characterization of radionuclides and minerals in river sediments. Appl. Radiat. Isot., 69, 184-195, https://doi.org/10.1016/j.apradiso.2010.07.020.

25. Beretka, J. \& Mathew, P. J. (1985). Natural radioactivity of Australian building materials, waste and byproducts. Health Phys., 48(1), 87-95, https://doi. org/10.1097/00004032-198501000-00007.

26. Orgun, Y. et al. (2007). Natural and anthropogenic radionuclides in rocks and beach sands from Ezine Region (Çanakkale), Western Anatolia, Turkey. Appl. Radiat. Isot., 65, 739-747, https://doi.org/10.1016/j.apradiso.2006.06.011.

27. NEA-OECD. (1979). Nuclear Energy Agency: Exposure to radiation from natural radioactivity in building materials. Report by NEA Group of Experts, OECD, Paris.

28. International Commission on Radiological Protection. (1991). Recommendations of the International Commission on Radiological Protection. Oxford: Pergamon Press.

29. El-Taher, A. \& Abdel Halim, M. A. K. (2014). Elemental analysis of soils from Toshki by using instrumental neutron activation analysis techniques. J. Radioanal. Nucl. Chem., 300, 431-435.

30. Al-Zahrani, J. H. \& El-Taher, A. (2014). Radioactivity measurements and radiation dose assessments in soil of Al-Qassim region, Saudi Arabia, Indian. J. Pure. Appl. Phys., 52, 147-154.

31. Uosif, M. A. M. \& El-Taher, A. (2006). The assessment of the radiation hazard indices due to uranium and thorium in some Egyptian environmental matrices. J. Phys. D Appl. Phys., 39, 4516-4521, https://doi.org/10.1088/00223727/39/20/032.

32. Uosif, M. A. M. \& El-Taher, A. (2008). Radiological assessment of Abo-Tartur phosphate, Western Desert, Egypt. Radiat. Prot. Dosim., 130(2), 228-235, https://doi.org/ 10.1093/rpd/ncm502.

33. El-Mamony, M. H. \& Khater, A. (2004). Environmental characterization and radioecological impacts of non-industries on the Red Sea coast. J. Environ. Radioact., 73, 151-168, https://doi.org/10.1016/j.jenvrad.2003.08.008.

34. El-Reefy, H. I. et al. (2010). Distribution of gamma-ray emitting radionuclides in the marine environment of the Burullus Lake: II. Bottom sediments. Environ. Monit. Assess., 169(1-4), 273-284, https://doi.org/10.1007/s10661-009-1169-1.

35. El-Taher, A. \& Madkour, H. A. (2011). Distribution and environmental impacts of metals and natural radionuclides in marine sediments in-front of different wadies mouth along the Egyptian Red Sea coast. Appl. Radiat. Isot., 69, 550-558, https://doi.org/10.1016/j.apradiso.2010.11.010.

36. El-Gamal, A., Nasr, S. \& El-Taher, A. (2007). Study of the spatial distribution of natural radioactivity in the upper Egypt Nile river sediments. Radiat. Meas., 42(3), 457-465, https://doi.org/10.1016/j.radmeas.2007.02.054. 
37. Ababneh, Z. Q. et al. (2010). Assessment of gamma emitting radionuclides in sediment cores from the Gulf of Aqaba, Red Sea. Radiat. Prot. Dosim., 141(3), 289-298, https://doi.org/10.1093/rpd/ncq182.

38. Salahel Din, K. \& Vesterbacka, P. (2012). Radioactivity levels in some sediment samples from Red Sea and Baltic Sea. Radiat. Prot. Dosim., 148, 101-106, https://doi.org/10.1093/rpd/ncq591.

39. El Arabi, A. M. (2005). Natural radioactivity in sand used in thermal radiotherapy at the Red Sea coast. J. Environ. Radioact., 101, 165-169, https://doi.org/10.1016/j. jenvrad.2004.11.002.

40. Khatir, A. S. et al. (1998). Radioactivity levels in the Red Sea coastal environment of Sudan. Mar. Pollut. Bull., 36, 19-26, https://doi.org/10.1016/S0025326X(98)90025-X.

41. El-Tahawy, M. S. et al. (1994). Natural and artificial radionuclides in the Suez Canal bottom sediments and stream water. Radiat. Phys. Chem., 44, 87-89, https://doi.org/10.1016/0969-806X(94)90110-4. 